\title{
Taxation, pension schemes and stakeholder wealth
}

Article

Accepted Version

Platanakis, E. and Sutcliffe, C. (2020) Taxation, pension schemes and stakeholder wealth. Advances in Taxation, 27. pp. 125-158. ISSN 1058-7497 doi:

https://doi.org/10.1108/S1058-749720200000027005 Available at https://centaur.reading.ac.uk/85993/

It is advisable to refer to the publisher's version if you intend to cite from the work. See Guidance on citing.

To link to this article DOI: http://dx.doi.org/10.1108/S1058-749720200000027005

Publisher: Emerald

All outputs in CentAUR are protected by Intellectual Property Rights law, including copyright law. Copyright and IPR is retained by the creators or other copyright holders. Terms and conditions for use of this material are defined in the End User Agreement.

\section{www.reading.ac.uk/centaur}

\section{CentAUR}

Central Archive at the University of Reading

Reading's research outputs online 


\title{
Taxation, Pension Schemes and Stakeholder Wealth
}

\author{
Emmanouil Platanakis ${ }^{\#}$ and Charles Sutcliffe*
}

24 August 2019

\# School of Management, University of Bath, Claverton Down, Bath, BA2 7AY, UK, email: E.Platanakis@bath.ac.uk Tel: +44(0) 1274 235311, ORCID: 0000-0003-1493-6339

* The ICMA Centre, Henley Business School, University of Reading, PO Box 242, Reading RG6 6BA, UK, email: c.m.s.sutcliffe@rdg.ac.uk Tel +44(0) 118378 6117, ORCID: 0000-0003-0187-487X, (corresponding author)

\section{ABSTRACT}

Although tax relief on pensions is a controversial area of government expenditure, this is the first study of the tax effects for a real world defined benefit pension scheme. First, we estimate the tax and national insurance contribution (NIC) effects of the scheme's change from final salary to career average revalued earnings (CARE) in 2011 on the gross and net wealth of the sponsor, government, and 16 age cohorts of members, deferred pensioners and pensioners. Second, we measure the size of the twelve income tax and NIC payments and reliefs for new members and the sponsor, before and after the rule changes. We find the total subsidy split is roughly $40 \%$ income tax subsidy; and $60 \%$ NIC subsidy. If lower tax rates in retirement and the risk premium effect of the exempt-exempt-taxed (EET) system are not viewed as a tax subsidy, the tax subsidy to members largely disappears. Any remaining subsidy drops, as a proportion of pension benefits, for high earners; as does that for NICs.

Key words: Pension schemes, Taxation, National Insurance Contributions, Universities Superannuation Scheme, Redistribution, Rule changes

JEL: G22, H20, J32

We wish to thank John Board (Reading), Dimos Andronoudis (Bristol), the referee; and participants in the British Accounting and Finance Association Conference, Westminster, and the $25^{\text {th }}$ Annual Global Finance Conference, Paris, for their comments on an earlier draft. 



\section{Taxation, Pension Schemes and Stakeholder Wealth}

According to the UK government, pension tax relief represents a major item of government expenditure that is of similar size to defence spending (HM Treasury, 2017). But despite this importance, the tax effects of pension schemes are under-researched. This may be because the interaction of the taxation and pension systems is "a maze of rules defying logic", Curatola et al, (2001). To help remedy this situation we examine the largest UK defined benefit (DB) occupational pension scheme (Universities Superannuation Scheme, USS) and its rule changes of 2011, and this is the first study of the tax effects of a real world defined benefit pension scheme. The UK system for taxing pensions (exempt-exempt-taxed, EET) is used by 18 of the 35 members of the OECD and 13 of the 28 members of the European Union (OECD, 2015) $)^{1}$, giving our results general relevance. In addition, we study two types of pension scheme - final salary and career average revalued earnings (CARE). We explore two related questions concerning pension taxation.

First, we estimate the difference between the gross and net effects of this rule changes for 16 age cohorts of members and pensioners ${ }^{2}$. Net effects are what ultimately matters to the sponsor ${ }^{3}$ and members, but previous researchers have only considered the gross effects of pension rule changes on age cohorts, e.g. Beetsma, et al. (2014), Chapman, et. al. (2001), Chen, et al. (2014), Draper, et. al. (2014), Hoevenaars, (2009), Hoevenaars (2011), Hoevenaars, et al. (2009), Hoevenaars, et al. (2007), Hoevenaars \& Ponds (2008), Lekniute, et al. (forthcoming), Platanakis \& Sutcliffe (2016) and Ponds (2003). Ignoring the tax effects gives a false picture of the gains and losses of a rule change. Previous researchers analyse the effects of rule changes on just the two main stakeholders - the sponsor and the members. But a third stakeholder is also affected by pension schemes - the government. We estimate the wealth effects of the rule changes on the sponsor and age cohorts of members net of both income tax and national insurance contributions (NICs), as well as the

\footnotetext{
1 The European Parliament's Committee on Economic and Monetary Affairs has urged "the broadest possible application of the EET principle" (European Commission, 2001). See Sutcliffe (2016) for the advantages and disadvantages of EET and TEE.

${ }^{2}$ When we use the term 'members' it generally includes pensioners and deferred pensioners.

${ }^{3}$ We assume throughout that the members' employer is also the scheme sponsor.
} 
effects on government tax revenues ${ }^{4}$. By including the government in the analysis we show that pension scheme rule changes can have a meaningful effect on government revenues. We also quantify the effects on members' wealth, both gross and net, from joining USS.

In 2015 the UK government released a consultation paper proposing major reform of the taxation of pensions (HM Treasury, 2015). This had the aims of reducing the cost of the pension tax subsidy, and increasing the incentives for pension saving to provide bigger pension pots to accommodate increased longevity. The ensuing public debate was substantial, but lacked relevant empirical evidence. Our second question addresses this gap by providing the first empirical analysis of the income tax and NIC payments and subsidies over the lifetime of members of a real world scheme. For a stable set of scheme rules, we investigate the size of the twelve individual components of the total income tax and NIC subsidy from joining USS to death, relative to a benchmark tax system ${ }^{6}$. In computing these tax subsidies, we use a taxed-exempt-exempt (TEE) system as our benchmark, and derive the conditions under which the tax revenue from an EET system has the same present value as that from a TEE system using a multi-period model. We do this both before and after the USS rule changes, and so effectively study two different schemes. We then use these estimates to consider the size and distribution of the national pension tax subsidy, and government proposals for the reform of pensions taxation.

Our research builds on the study by Platanakis \& Sutcliffe (2016) (P\&S) who quantify the gross effects of the USS rule changes on the wealth of two stakeholders - the sponsor and age cohorts of the members. We extend their analysis by incorporating tax and NIC payments and reliefs, which enables us to model the effects on a third stakeholder - the government. The tax system is complex, and we model twelve major types of tax relief

\footnotetext{
${ }^{4}$ We include NICs in our model because they have become a de facto tax, with the government including them in its pension tax expenditure figures (HM Revenue and Customs, 2016). When we use the term 'tax' it generally includes NICs.

${ }^{5}$ The net wealth effects of early retirement on the members, sponsor (USS) and government were estimated by Simon (1987).

${ }^{6}$ The choice of benchmark is crucial (Knox, 1990; Dilnot and Johnson, 1993, Emmerson, 2014).
} 
and payment generated by pension schemes - eight for members, three for the sponsor, and one for both. The P\&S model has a horizon date of 2065 , and there will be many changes to the tax system during this period which are hard to predict. Our quantification relies on the tax system in force at the time of the rule changes. This provides estimates of the net wealth and taxation effects the decision makers might reasonably have expected to result from these rule changes.

The principal rule change was the closure of the final salary scheme to new members, who were offered a new CARE section instead. ${ }^{7}$ We find the changes in scheme rules had important implications for the taxation of members, the government and the sponsor. When tax effects are included in the P\&S model, the youngest age cohorts experience a wealth reduction that is about $20 \%$ smaller than the gross effect, the sponsor's wealth increase is almost $f 1 \mathrm{bn}$. smaller, and the government's tax revenues are almost $f 3 \mathrm{bn}$. higher. Joining the pre-2011 final salary scheme was considerably more beneficial for members wealth than the post-2011 CARE section by about $£ 85,000$ (both gross and net) per head. But even after the rule changes, scheme membership remained attractive, and joining the post-2011 CARE section in 2011 led to a net (gross) wealth increase of about $£ 98,000(£ 46,000)$. The present value of the income tax relief for members of both the CARE section and the pre-2011 final salary scheme is roughly $f 26,500$ per head, and the NIC relief for both members and the sponsor has a present value of about $£ 20,000$ in each case. Therefore NICs represent $60 \%$ of the government pensions subsidy. However government policy has focussed exclusively on reducing the income tax subsidy, and ignored the NIC subsidy. Part of the explanation for this may be that the government has substantially overestimated the size of the income tax subsidy. We go on to argue that the government's claim of two thirds of the tax subsidy going to higher earners is an exaggeration (HM Treasury, 2015).

This paper has the following structure. In Section I the model used by P\&S to quantify the gross wealth changes caused by the rule changes is summarized; and in Section II we outline the relevant aspects of the UK tax system in 2011. Estimates of the net wealth effects of the rule changes appear in Section III, while Section IV

${ }^{7}$ Subsequently, in 2016 the final salary section was closed to further contributions, and all active members transferred to the CARE section. 
measures the net and gross increases in members' wealth from joining USS. In Section V there is a life cycle analysis of the tax subsidy members receive, and the increase in net and gross wealth of members from joining USS. Section VI contains a discussion of government policy on reducing and reforming the pension subsidy. Finally, Section VII has our conclusions.

\section{Summary of the P\&S model}

USS was founded in 1975 as a final salary scheme for UK universities and related institutions. By 2018 it was the largest pension scheme in the UK, and the $30^{\text {th }}$ largest in the world with 420,000 active members, deferred pensioners and pensioners. It is a multi-employer scheme with 374 separate sponsors (or institutions), and assets valued at $£ 64$ billion in 2018 . The 2009 actuarial valuation of USS produced a funding ratio of $75 \%$ due to a USS decision to de-risk the scheme's investments, the drop in the stock market and increased longevity; coupled with very low interest rates. This prompted a review, followed by the 2011 rule changes. These changes were challenged by the members and pensioners of USS, represented by the University and College Union (UCU), leading to lengthy industrial action by members of the UCU. In October 2011 USS closed its final salary scheme to new members, set up a CARE scheme for new members, moved from balance-of-cost to a cap-and-share rule for setting the sponsor and members' contribution rates, capped the indexation of deferred pensions and pensions in payment, linked the retirement age to that for state pensions, and increased the contribution rate for the sponsor and members ${ }^{8}$. These were the most significant rule changes that USS had made since its foundation.

The P\&S model incorporates lump sum payments on retirement, deferred pensioners, limited price indexation, spouses' pensions, increases in the retirement date, both final salary and CARE sections, and consumer price indexation (CPI) of the accrued benefits of CARE section active members, deferred pensioners, and pensions in payment. In addition, the P\&S model computes final salaries using the retail price index (RPI). P\&S disaggregated members, future members, pensioners and deferred pensioners of the two sections of USS

\footnotetext{
${ }^{8}$ For a fuller description of the rule changes and their model see Platanakis and Sutcliffe (2016). USS undertook
} further major rule changes in 2016, and additional reform is proposed for 2019. 
(final salary and CARE) into 50 age-based groups based on their age in 2011. For each cohort P\&S estimated the change in gross wealth in 2011 resulting from the change in cash flows over the period 2011-2065 due to the rule changes. P\&S treat the 374 USS sponsors as a single entity, and compute the pre-tax change in the sponsor's 2011 gross wealth due to the change in cash flows over the 2011-2065 period. The voluntary purchase of added years and money purchase additional voluntary contributions (AVCs) is excluded from the model. The P\&S model did not consider consequential effects of the rule changes on the membership or sponsor, such as changes in the number employed, salaries, conditions of service, consumption, etc.

For the period between 2011 and 2065 P\&S forecast asset returns, inflation, academic salaries, the size of the 50 age groups, and academic longevity; and then use this information to forecast scheme liabilities each period. They model how USS responds to changes in the funding ratio, and estimate the USS asset allocation and contribution rates each period. This permits them to compute the gross cash flows each period between the various age cohorts and sponsor. Finally these cash flows are discounted back to 2011 to give the gross change in wealth for each age cohort and the sponsor. P\&S solve their model 5,000 times for different forecasts to estimate the distribution of gross wealth changes in 2011 . They found a pre-tax increase of $£ 30$ $\mathrm{bn}$. in the gross wealth of the sponsor, and a corresponding decrease of $f 30 \mathrm{bn}$. in the gross wealth of members.

\section{The taxation of pensions ${ }^{9}$}

Under the EET system, pension contributions by the sponsor and active members are tax deductible, returns on the pension fund (i.e. dividends, capital gains and interest) are tax exempt, and the pension income received by pensioners is subject to the normal income tax rules. For example, if the contribution rate for active members is $7.5 \%$ of their gross salary, and a member's income tax rate is $40 \%$, the member receives income tax relief of $7.5 \times 0.4=3 \%$ of their gross salary. This effectively reduces the cost of member pension contributions to $4.5 \%$ of their gross salary.

\footnotetext{
${ }^{9}$ For a history of the taxation of pensions in the UK see Blake (2003).
} 
In the UK there are some exceptions to a pure EET system. If the value of a UK member's accrued benefits increases by more than the annual allowance, income tax is payable by the member on the excess. Pension funds pay stamp duty when they buy UK equities and property, and (at second hand) they pay corporation tax when they receive dividends from UK companies paid out of corporate net profits for which they do not receive offsetting tax relief. Since these taxes reduce the size of the pension fund, those responsible for scheme funding (the sponsor in a balance-of-cost scheme, and the members and sponsor in a cap-and-share scheme) must make additional contributions to compensate for this reduction in funding. A further exception to a pure EET system is that when they retire pensioners can choose to take a tax free lump sum of up to a quarter of the value of their accrued benefits, resulting in a reduction in their pension as determined by the commutation factor used by the scheme actuary. Finally, if the value of a pensioner's accrued benefits at retirement exceeds the lifetime allowance, a one-off tax of $25 \%$ must be paid by the pensioner on the excess. The actual EET tax system, as well as the pure EET and TEE systems, are summarised in Table 1.

TABLE 1 around here

As well as paying income tax on their earnings, UK employees must also pay NICs ${ }^{10}$. These payments are effectively a tax on earned income that accrues state pension benefits, and are based on gross income before the deduction of any occupational pension scheme contributions. NICs follow a TEE model. The sponsor also has to pay NICs on members' gross salaries. No NICs are payable on the investment income of the pension fund or on pensions received. However, there are exceptions to a pure TEE system for NICs. Sponsors are exempt from paying employers' NICs on their pension contributions ${ }^{11}$, and members are

${ }^{10}$ We do not model the state pension received by members, except when computing marginal tax rates in retirement, nor the income tax paid on these pensions or pension credits. The rule changes do not affect members' state pensions.

${ }^{11}$ While the sponsor receives this tax relief, scheme members may benefit indirectly due to the reduction in the net cost of pension contributions by the sponsor. 
exempt from paying NICS on the sponsor's contributions ${ }^{12}$. Salary sacrifice for pensions is a further exception to the TEE model for NICs where the sponsor agrees to make a member's pension contributions, and reduces the member's gross salary for NIC purposes by a corresponding amount. The result is that both the member and sponsor avoid paying NICs on the member's pension contributions. The NIC payments by the members and sponsor for the actual and pure TEE systems are summarized in Table 2 .

TABLE 2 around here

These twelve tax effects are shown in Figure 1, along with the three gross contribution and pension payments between the sponsor and members analysed by P\&S. The tax effects are: $(A)$ income tax relief received by active members on their contributions, (B) salary sacrifice for member pension contributions which reduces member NICs, (C) income tax free lump sums, (D) the exemption of members from paying NICs on the sponsor's contributions, (E) income tax relief to members on the sponsor's pension contributions, (F) income tax paid by pensioners for exceeding the lifetime allowance, $(G)$ income tax paid by members for exceeding the annual allowance, $(\mathrm{H})$ income tax paid by pensioners on the pension payments they receive, (I) stamp duty paid by the pension fund on purchases of UK property and equities, and the corporation tax deducted from UK dividends received ${ }^{13},(\mathrm{~J})$ salary sacrifice for member pension contributions which reduces sponsor NICs, (K) the receipt of corporation tax relief by the sponsor on their pension contributions, which only applies if the sponsor has a taxable profit, and (L) the sponsor's exemption from paying employer's NICs on their pension contributions. Details of these 12 taxes and the estimation of their coefficients are in Appendix 1.

Figure 1 around here

12 The UK government estimated the total cost in 2011-12 of these two NIC exemptions at $f 14.8 \mathrm{bn}$. (HM Revenue and Customs, 2016).

13 This tax falls on those responsible for scheme funding. For a cap-and-share scheme this is both the members and sponsor. 


\section{Post-tax wealth effects of the rule changes}

We now address our first question, and estimate the tax and NIC payments and reliefs associated with both the pre and post-2011 USS schemes, and hence the effect of taxation on the wealth effects of the rule changes for 16 age cohorts. After including the taxes and reliefs set out equations A1 to A12 in Appendix 1 , and estimating the additional model parameters in the ways described in Appendix 2, we solve the P\&S model for the fix-mix asset allocation.

We use the Diebold and Li (2006) modification of the Nelson and Siegel (1987) model together with quarterly data on zero coupon UK government bonds to estimate the parameters of the UK yield curve. With quarterly data from 1993 to 2010 for UK, US and EU equities, UK property, UK dividends, US dividends, hedge funds, commodities, UK inflation (both RPI and CPI) and the three estimated Diebold and Li yield curve parameters, we fit a VAR(1) model to these 13 variables. We then forward iterate this VAR(1) model to produce 5,000 sets of forecasts (i.e. scenarios) of asset returns, inflation rates, and yield curves until the horizon date. We use data on academic salary levels for each age cohort from HESA (2014) to estimate the relationship between age and salary, to which we add inflation forecasts from the VAR(1) model. We forecast the size of the age cohorts by fitting time trends to USS membership data, and generate 5,000 forecasts of the size of the various age cohorts and their salary levels.

Life expectancy for each age cohort comes from ONS (2014). As USS members have a greater life expectancy than the general population, the national life tables are uprated by six years, so that at age 65 USS pensioners are expected to live until they are 90 years of age, USS (2012). The actuarial model of Board and Sutcliffe (2007) is then used to forecast the liabilities for each age cohort. In order to model the USS procedure for setting the contribution rate we use the same discount rate as USS when computing the liabilities, i.e. the average of the current yield curve for the next 20 years plus $1.7 \%$ (USS, 2014). The expanded P\&S simulation model is solved 5,000 times to generate the gross and net cash flows between 
the members, pensioners, sponsor and government. These cash flows are discounted back to 2011 at the appropriate rate from the UK riskless rate yield curve estimated by the VAR(1) model for that scenario to compute the wealth changes for the various participants. P\&S also discounted the gross cash flows using stochastic discount factors (SDFs), and obtained broadly similar results to those generated using riskless discount rates, which implies that our results are robust to the use of SDFs.

Figure 2 around here

Figure 2 shows the mean percentage drop in member wealth (i.e. the drop in the NPV of being a member of USS, computed using the riskless discount rate for that scenario) for each age cohort due to the rule changes. There are separate pairs of lines for final salary members of the pre-2011 scheme who remain in the final salary section post-2011, and those joining the post-2011 CARE section, who would otherwise have joined the pre-2011 final salary scheme if the rules had not changed. These pairs of lines overlap for the 27 to 37 year age cohorts because members are assumed to join USS at a range of ages. For both CARE and final salary members the upper line represents the gross percentage drop in wealth due to the rule changes, and the lower line is the corresponding net percentage drop in wealth. The gaps between each pair of lines are due to the income tax and NICs subsidies received by members. Since the net lines lie below the gross lines, the net percentage reductions in members' wealth are smaller than the gross percentage reductions; with the difference leading to a drop in government tax revenues. For those members (and future members) in age cohorts 17 to 37 the net percentage wealth reduction is roughly $20 \%$ lower (e.g. $45 \%$ not $65 \%$ ) than the gross percentage wealth reduction; while for older members of the final salary section the difference becomes progressively smaller, dropping to zero for pensioners.

Figure 3 around here

Figure 3 presents the information in Figure 2 in terms of the average loss of $f$ per person for each age cohort due to the rule changes. For the 17 to 37 years age cohorts, the reduction in the loss from the rule 
changes due to taxation and NICs subsidy is $£ 3,000$ to $£ 5,000$ per person (e.g. a gross loss of $£ 90,000$ is reduced to a net loss of $£ 85,000$ ). It becomes much smaller for older cohorts, dropping to zero for retired cohorts. Figure 4 plots the differences between each pair of lines in Figure 3. It also has the $90 \%$ and $10 \%$ percentiles for these differences. These percentile lines show considerable dispersion in the outcomes for the youngest cohorts; which declines with age, becoming zero for pensioners.

Figure 4 around here

Due to the rule changes, the present value of the gross cost of USS to the sponsor falls from $f 113.7 \mathrm{bn}$. to $f 83.8 \mathrm{bn}$., i.e. a rise in sponsor gross wealth in 2011 of $f 29.9 \mathrm{bn}$. When the tax and NIC effects are included, the net cost to the sponsor of the rule changes drops from $f 104.0 \mathrm{bn}$. to $f 75.0 \mathrm{bn}$., i.e. a rise in 2011 sponsor wealth of $£ 29.0 \mathrm{bn}$. Therefore the tax and NICs subsidy to the sponsor shows a modest reduction of $£ 0.9$ bn., from $£ 9.7 \mathrm{bn}$. to $£ 8.8 \mathrm{bn}$.

Figure 5 around here

Figure 5 plots the cumulative increase in the NPV of government tax and NIC revenues caused by the rule changes. After about 15 years the cumulative figure becomes positive, rising to an increase in the NPV of government wealth of $£ 2.86 \mathrm{bn}$. by 2065 . This figure, together with the drop of $£ 0.9 \mathrm{bn}$. in the sponsor's tax subsidy, implies the collective tax subsidy to members drops by $£ 1.96 \mathrm{bn}$.

\section{Life cycle analysis of the wealth benefits to members from joining USS}

We examine the gain to members from joining USS for just the two youngest cohorts (17 and 22), and compute the NPV in 2011 of all their cash flows, both gross and net, related to joining USS throughout their lifetimes ${ }^{14}$. The older age cohorts had accrued benefits in 2011, and so cannot be included in a life cycle analysis of tax and NIC payments and reliefs because our model does not capture the contributions

\footnotetext{
${ }^{14}$ It also includes the cash flows for the next 25 years for pensioners in 2065.
} 
and tax reliefs involved in creating these accrued benefits. The post-2011 CARE section and the pre-2011 final salary scheme have substantially different rules, and to enable a comparison of the benefits from joining them we make the counterfactual assumption that members of the 17 and 22 age cohorts were able to join the pre-2011 final salary scheme.

In each case joining USS leads to a substantial increase in wealth, although the wealth increase from joining the pre-2011 final salary scheme is much larger than for the post-2011 CARE section. The gross mean NPV for those in cohorts 17 and 22 from joining the final salary scheme is $£ 133,000$, and their net mean NPV after allowing for income tax and NIC payments and reliefs is $f 181,000$. The corresponding figures for the CARE section are a gross wealth increase of $£ 46,000$, and a net wealth increase of $£ 98,000$. The difference of about $£ 85,000$ (both net and gross) between the pre-2011 final salary scheme and the post-2011 CARE section (as shown in Figure 3) is because the final salary scheme was more generous, offering higher benefits for members.

\section{Life cycle analysis of members' income tax and NIC reliefs and payments}

We now turn to our second question of disaggregating the lifetime income tax and NIC reliefs and payments, and estimating the total tax subsidy to members and sponsor. To do this we need a benchmark tax system against which to measure the tax reliefs and payments. Arguably, what matters to employees is their total remuneration, with substitution between salary and pension benefits. As an alternative to offering a pension scheme, we assume salaries are increased by the cost to the sponsor of the pension scheme, i.e. a cost neutral switch for the sponsor. Members are assumed to divert this extra salary into either tax sheltered savings, such as Investment Savings Accounts (ISAs), i.e. a TEE system ${ }^{15}$, or into consumption ${ }^{16}$. A survey by LCP (2017) found $84 \%$ of FTSE 100 companies offer employees a cash

\footnotetext{
${ }^{15}$ Like pension funds, holders of ISAs cannot reclaim any tax on the dividends they receive.

${ }^{16}$ The benchmark used by Dilnot and Johnson (1993) and Knox (1990) was personal equity plans (PEPs), which were replaced by ISAs in 1999.
} 
alternative to pensions, which supports the use of an increase in salary and TEE as the benchmark for income tax, although this may not be the case for all universities.

\section{Va. Income tax payments and reliefs}

Table 3 has the present values per head of the estimated income tax payments for members of the two youngest cohorts (17 and 22) over their lifetime as members of the post-2011 CARE section and the pre2011 final salary scheme. The tax subsidy is the tax for a pure TEE system (the benchmark), less that for the actual EET system.

TABLE 3 around here

In Table 3 the present values of the stamp duty and dividend tax (I), the tax on members contributions (A), the tax on the sponsor's contributions $(\mathrm{E})$, and the tax on pensions $(\mathrm{H})$ are available from the expanded P\&S model. Allowance is made in Table 3 for changes in scheme funding over the 2011-2065 period, which we compute using the procedures in Appendix 3 (TXM and TXS). In 2011 USS had a deficit of $£ 2.81 \mathrm{bn}$, while the present value in 2011 of the expected surplus in 2065 for the post- 2011 scheme is $£ 4.80 \mathrm{bn}$. The corresponding figure for the pre-2011 scheme is a deficit of $-£ 9.67 \mathrm{bn}$. in 2065 . Therefore, during the 2011-2065 period the present value in 2011 of the post-2011 scheme's funding improves by $f 7.61 \mathrm{bn}$, and for the pre-2011 scheme it worsens by $£ 6.86 \mathrm{bn}$. Under a TEE system the $f 7.61 \mathrm{bn}$. that flows into the post-2011 scheme is taxed, but in 2065 the surplus of $£ 4.80 \mathrm{bn}$. is not required to be paid out as pensions and subject to taxation, and the elimination of the opening deficit of $f 2.81 \mathrm{bn}$. relates to previous cohorts. This leads to an overstatement of the tax paid by cohorts 17 and 22 during the 2011-2065 period under a TEE system, relative to a situation with no surplus or deficit ${ }^{17}{ }^{18}$. The reverse situation applies to the $f 6.86$

\footnotetext{
${ }^{17}$ The rule changes mean cohorts 17 and 22 who entered the CARE section receive a worse deal than those already in the final salary scheme because the big deficit in 2011 is entirely attributable to the final salary members, not the CARE section members. While cohorts 17 and 22 make higher contributions to help rectify this deficit, leading to the receipt of higher tax relief; they do not receive increased pensions on which they make tax payments.

${ }^{18}$ For a DB scheme the valuation of the pension pot relies on actuarial assumptions and procedures. Following USS, P\&S employ various actuarial valuation procedures which depart from economic reality, e.g. they use the gilt rate
} 
bn. that flows out of the pre-2011 scheme, leading to an understatement of the tax paid under the TEE system. This adjustment to allow for changes in funding reduces the CARE income tax subsidy by $£ 3,000$, and increases the final salary tax subsidy by $£ 2,500$. The total tax subsidies in Table 3 are broadly similar for CARE and final salary members, with an income tax subsidy of $£ 26,600$ for the CARE section, and $£ 25,300$ for the final salary scheme.

Some commentators have argued that two of the tax reliefs implicit in an EET system, relative to TEE, should not be regarded as subsidies. These are the lower tax rate in retirement, and that the EET system delays the payment of income tax. The EET system taxes pension income when it is consumed, which spreads taxable income over a members' working and retired years (i.e. tax spreading or smoothing), and does not concentrate it in the years of pension contributions, as does TEE. This usually leads to a lower tax rate for pensions. Emmerson $(2014,2016)$, Emmerson and Johnson $(2016,2018)$ and Adam and Waters (2018) argue that this is an advantage of the EET system as it spreads taxation over a person's lifetime, with pension contributions treated as deferred wages that are locked away until received as a pension. Taxing pensions at a higher rate when a member is contributing, rather than at a lower rate when they are a pensioner can be viewed as unfair over-taxation. In support of Emmerson's view, Mirrlees et. at. (2011, p. 327) advocate offering members a free choice between taxation at their marginal rates when contributing or when retired, i.e. a choice between EET or TEE. The expanded P\&S model gives CARE and final salary tax rates that are lower by an average $5.12 \%$ and $4.16 \%$ respectively when in retirement than when working. Ignoring lower income tax rates in retirement reduces the CARE subsidy by $f 5,100$, and the final salary subsidy by $f 6,700$.

plus $1.7 \%$ as the discount rate. For an approach to valuation based on economics see Platanakis and Sutcliffe (2017). Therefore the change in scheme funding may not be accurately measured by the P\&S model, making the adjustment for the change in scheme funding subject to error. Error! Main Document Only.Different USS scheme valuations would alter our adjustments to the CARE and final salary tax subsidies which allow for changes in USS funding levels. The USS valuation procedures are very widely used by pension schemes, and so this issue has general relevance." 
Under a pure EET system the tax on pension contributions that would be paid immediately under a pure TEE system is invested by the scheme, with the proceeds used to pay pensions. The EET tax payments are then discounted back to the present. This present value exceeds that for the TEE system by the extent to which the investment return on the pension fund exceeds the discount rate. Since DB benefits are fixed by the rules of the scheme, the investment returns on the tax that would have been paid under TEE reduces the contributions required from the sponsor and members. Such contributions are tax exempt under an EET system. Therefore the risk premium earned by the scheme from delaying the payment of taxes under EET, relative to TEE, benefits those responsible for funding the scheme; supporting the view that this gain is not a government subsidy, but a reward for risk bearing by the scheme ${ }^{19}$.

To quantify the benefit of delaying the payment of tax under EET, we use equation (A25) in Appendix 4. This appendix shows that, given the assumptions that members' income tax rates are the same when employed and retired, and that each period the rate of return on the investments is equal to the discount rate; the present values of the tax payments under pure TEE and EET systems for a single age cohort are equal. Equation (A25) shows there are five main differences between a pure TEE system and the actual EET system ${ }^{20}$. The second and third terms in equation (A25) are the stamp duty and dividend tax (I) which is included in Table 3, while the lump sum tax relief is implicit in the tax paid on pensions by members $(\mathrm{H})$ in Table 3. The first term in equation (A25) is due to the interaction of the discount rates, investment rates, pension contributions, changes in the funding ratio, tax rates in employment and the tax rate in retirement. We disaggregate this term into its three components - (a) differences between the discount rate and the corresponding rate of return on the investments each period, (b) changes in the scheme

\footnotetext{
${ }^{19}$ Since the investment risk of a DB scheme is not shared between the scheme and the government, the tax system has no effect on the riskiness of the assets chosen by a DB scheme. However in a defined contribution (DC) scheme the risk premium earned under an EET system from delaying taxation leads to a larger final pension pot, which is then subject to taxation. These investment returns increase the size of the pension pot, and are shared with the government via the tax on the increased pension. This induces members to invest in riskier assets than otherwise (Romaniuk, 2013).

${ }^{20}$ These tax effects are unaffected by the rule change from balance-of-cost to cap-and-share.
} 
surplus or deficit, and (c) lower income tax rates for pensioners than for active members. Since these three effects interact, they cannot be disaggregated in a unique manner, and the risk premium in Table 3 is an illustrative disaggregation. To do this we subtract the effects of both a lower tax rate in retirement and an increase in funding (TXM and TXS) from the first term in equation (A25), and attribute the remainder to the risk premium effect. Ignoring this risk premium effect reduces the CARE income tax subsidy by $£ 12,000$, and the final salary subsidy by $f 8,500$. The last row of Table 3 shows that when these two effects are excluded, the income tax subsidy drops by about $60 \%$ to $£ 9,400$ for CARE members, and $£ 10,000$ for final salary members.

\section{Vb. NIC payments and reliefs}

The NICS are already on a TEE basis and come from the expanded P\&S model, but we adjust the numbers to allow for the change in USS funding over the 2011-2065 period using the procedures in Appendix 3 to estimate the terms SSM, NRM, SSS and NRS. The total NIC relief for members of the 17 and 22 cohorts $\left(N C F^{m}\right)$ is the sum of members' salary sacrifice relief $(B)$ and exemption from employee NICs on the sponsor's pension contributions (D); less the two effects due to the increase in funding, which are the increase in members' salary sacrifice relief on their own NICS $\left(S S M_{i}\right)$, and the increase in relief from paying NICs on the sponsor's pension contributions $\left(N R M_{i}\right)$ :-

$$
N C F_{i}=N^{m_{i}}+N S_{i}^{m_{i}}-S S M_{i}-N^{2} M_{i}
$$

where $N^{m}$ is the NIC exemption for active members in age cohort $i$ on their contributions due to salary sacrifice, and $N S^{m}{ }_{i}$ is the NIC exemption for active members in age cohort $i$ on the sponsor's pension contributions. These two cohorts also generate NIC relief for the sponsor $\left(N C F_{i}^{S}\right)$ due to salary sacrifice (J) and exemption from sponsor NICs on the sponsor's pension contributions (L); less the two effects due to the increase in funding, which are the increase in the sponsor's salary sacrifice relief on member pension contributions $\left(S S S_{i}\right)$, and the sponsor's relief from paying NICs on their pension contributions $\left(N R S_{i}\right)$ :-

$$
N C F_{i}{ }_{i}=N^{s}{ }_{i}+N S_{i}^{s_{i}}-S_{S S} S_{i}-N R S_{i}
$$


where $N^{s} i$ is the NIC exemption for the sponsor on the salaries of members in age cohort $i$ who have opted into salary sacrifice, and $\mathrm{NS}^{s}$ i is the NIC exemption for the sponsor on their pension contribution for cohort $i$. Table 4 shows the present values of these reliefs for members of the two youngest cohorts (17 and 22) and for the sponsor. A switch to a pure TEE system for income tax would mean that the stamp duty and dividend tax payments cease; and the risk premium benefit is lost. These two effects lead to a change in the cost-neutral salary increase under our benchmark TEE system, which generates changes to the NICs for members and sponsor. The net effects appear in Table $4^{21}$. For the CARE section, members receive an NIC subsidy of $£ 20,000$, while the sponsor receives a subsidy of $£ 19,200$. The final salary scheme involves NIC subsidies of $£ 22,200$ for members, and $£ 23,800$ for the sponsor. So the NIC subsidy for the CARE section is $£ 2,200$ lower for members, and $£ 4,500$ lower for the sponsor.

TABLE 4 around here

With a zero rate for pensioners, the TEE system for NICs does not allow tax spreading. Since members face regressive NIC rates, which drop from $11 \%$ to $1 \%$ for incomes over $£ 43,875$, the lack of tax spreading for NICs is beneficial to members, some of whom would face a higher NIC contribution rate in retirement. Adopting the view of Mirrlees et al. 2011, this lack of tax spreading for NICs should not be viewed as an additional benefit for members. Sponsors face progressive NIC rates which rise from $9.1 \%$ to $12.8 \%$ for incomes over $£ 40,040$. They would benefit from tax spreading, although such tax spreading would present a substantial administrative challenge.

\section{Vc. Other possible effects from a switch to higher salaries}

A number of other possible effects have not been incorporated in the analysis in sections $\mathrm{Va}$ and $\mathrm{Vb}$. Due to the conversion of pensions into higher salaries, as assumed by the TEE benchmark, the marginal rates

${ }^{21}$ The increases in NICs for the sponsor and members in Table 4 from a move to a pure TEE system are the risk premium subsidy minus the stamp duty and dividend tax (I) figures in Table 3, multiplied by the marginal NIC rates for the members and sponsor in Appendix 2. 
of income tax and NICs for both members and the sponsor may change, and this may affect the tax effects computed above in three different ways. First, members income tax relief, relative to the benchmark, may be understated because increasing members' salaries by the cost to the sponsor of providing pensions could push some members into a higher income tax band (probably from $20 \%$ to $40 \%$ ). This leads to an understatement of their income tax subsidy; although for members already paying the $40 \%$ rate, or whose increased salary is less than $£ 42,055$, there is no effect. Second, the salary increase may lead to members' relief from NIC payments, relative to the TEE benchmark, being overstated. When their salary exceeds $£ 43,875$ members experience a drop in their marginal NIC rate from $11 \%$ to $1 \%$. Therefore the marginal rate of NIC relief for salary sacrifice and the sponsor's contributions for some members may be overstated; although for those members already being paid more than $£ 43,875$, or whose increased salary is less than this sum, there is no effect. Finally, the NIC relief for the sponsor may be understated because, for incomes above $f 40,040$, the employer's NIC rate rises from $9.1 \%$ to $12.8 \%$. However, for those already earning over $£ 40,040$, or whose increased salary is less than this threshold, there is no effect on the sponsor's NIC relief.

The size of these three effects is reduced by the sponsor's need for cost neutrality. The higher salaries, coupled with higher employer's NIC rate for salaries over $£ 40,040$, mean the sponsor must make greater employer's NIC payments when pensions are converted into higher salaries. To remain cost neutral the sponsor is unable to pass on all of their pension contributions in the form of higher salary to members, which tends to reduce the size of each of the three effects above.

\section{Vd. Total income tax and NIC subsidy}

Table 5 summarises the income tax and NIC subsidies to members and the sponsor in Tables 3 and 4 . Despite the substantial differences in rules between the post-2011 CARE section and the pre-2011 final salary scheme, their subsidies are of a broadly similar magnitude, with roughly an extra $£ 5,700$ more subsidy for the final salary scheme due to the higher NIC subsidies. Accepting that many approximations 
are involved, the NIC subsidy for CARE section members and the sponsor is approximately $f 21,000$ in each case, or $30 \%$ of the total income tax and NIC subsidy. The income tax subsidy for CARE members is higher at $£ 26,500$, or $40 \%$ of the total subsidy ${ }^{22}$. Therefore $60 \%$ of the government pension subsidy takes the form of a NIC subsidy, largely due to NICs on the sponsor's contributions for both the sponsor and members being charged on an exempt-exempt-exempt (EEE) basis (see Table 2). In addition, Tables 4 and 5 reveal that $13 \%$ to $17 \%$ of the total subsidy, and $19 \%$ to $28 \%$ of the NIC subsidy, is due to salary sacrifice. Two aspects of the total subsidy which have been argued not to represent a subsidy (lower tax rates in retirement and the risk premium available with EET) increase the total subsidy (tax and NICs) by $20 \%$ to $40 \%$, and the tax subsidy by $90 \%$ to $260 \%$ (see tables 3 and 5). So, if these two items are excluded, the tax subsidy to members largely disappears, while the total subsidy is substantially reduced.

TABLE 5 around here

\section{Government taxation policy}

The UK government view is that "the cost of tax and NIC relief on pensions savings is one of the most expensive sets of relief offered by the government. In 2014 to 2015 this cost around $f 48$ bn. .... In 2014 to 2015 the government also collected around $f 13 \mathrm{bn}$. in tax from pensions in payment" (HM Treasury, 2016). Most commentators have followed the government and quoted similar numbers ${ }^{23}$. To reduce the cost of this tax subsidy, increase incentives for saving, and equalise the distribution of tax relief between high and low earners, the government has made two alternative reform proposals (Pickard, et al. 2016, Thurley, 2017).

22 The proportions for the final salary scheme are broadly similar to those for the CARE section, with an income tax percentage that is a bit lower at $36 \%$.

${ }^{23}$ For example, Johnson (2014) gives $£ 54 \mathrm{bn}$. as the total annual cost of income tax and NIC relief on pensions. 
The first proposal is a switch from EET to a TEE income tax system ${ }^{24}$. There would be no tax relief on pension contributions ${ }^{25}$; and no income tax on pensions. So members would lose the tax spreading advantage of the EET system. They would also lose the risk premium effect and the tax free lump sum. This reform would not affect the large NIC subsidy for both members and the sponsor, where the sponsor's pension contributions have an EEE system for both the members and sponsor. Emmerson (2016) has written that NICs on "employer pension contributions are treated extremely generously. ... This is an opaque subsidy that is difficult to justify". Similarly Mirrlees et al. $(2011$, p. 319) say that "the current system (of NICs) provides a large subsidy to employer contributions to pensions", and Hills (2005) has written that "the NIC treatment of employer contributions constitutes one of the most favourable elements of the system". This exemption of sponsors from making NICs on their pension contributions, but not their salary payments, biases sponsors to favour remuneration in the form of pensions rather than salary.

The alternative government proposal is to stick with an EET system, but with a flat rate of income tax relief for pension contributions by all members, e.g. $30 \%$ rather than $20 \%$ or $40 \%$. Those members with a tax rate of $40 \%$ would pay more income tax when they make contributions, e.g. $10 \%$ of their contributions, while those with a $20 \%$ tax rate would receive additional tax relief, e.g. $10 \%$ of their contributions. The tax free lump sum and the large NIC exemptions for the sponsor and members would remain, as would the risk premium and the lower tax rate in retirement.

As well as reducing the cost of the pension subsidy, the government also wishes to change the distribution of tax relief since it claims that "over two thirds of pensions tax relief currently goes to higher and additional rate taxpayers" (HM Treasury, 2015). However, this statement is misleading so far as income

${ }^{24}$ Only four of the 35 OECD members use a TEE system for pension taxation (OECD, 2015).

${ }^{25}$ It is not clear whether the sponsor's contributions would also be taxed, but if they were not taxed the sponsor's contributions would be EEE. 
tax relief is concerned, as the Treasury appears to be ignoring the income tax that will be paid in retirement. Those whose marginal income tax rate is the same when working and retired receive no income tax subsidy, other than a tax-free lump sum and the risk premium effect, which some do not regard as a subsidy but a reward for risk bearing. For those with a lower tax rate in retirement, it is debatable whether this is a tax subsidy, or just permissible tax spreading. Although inconsequential in 2011 and ignored in our analysis, as a member's pension benefits rise they will increasingly be subject to the negative effects of exceeding the annual and lifetime allowances, and their income tax relief will drop as a proportion of their pension benefits ${ }^{26}$. This suggests that, relative to a TEE benchmark, the distributional effects of pension income tax relief are modest. One view is that the income tax relief amounts to just the tax free lump sum, reduced or constrained by the annual and lifetime allowances. Since the lump sum is a constant proportion of pension benefits, while the annual and lifetime allowances increase the taxation of high earners, tax relief drops as a proportion of pension benefits for high earners. The substantial NIC subsidy to members is at a higher rate for those on lower salaries, again giving a larger proportionate benefit to lower paid members.

There are a number of reasons why government estimates of the income tax subsidy to members are overstated (Emmerson and Johnson, 2018). First, Her Majesties Revenue and Customs (HMRC) use a benchmark of TTE, not TEE; so the non-taxation of investment income (apart from the payment of stamp duty and dividend taxes) is treated as a subsidy. Second, HMRC's calculation of the net cost of pension tax relief subtracts the tax paid by pensioners in the current year from the tax relief received by active members in the current year to give the net cost. Because the number of pensioners, wage levels, contribution rates and longevity increase over time, $\mathrm{HMRC}^{\prime}$ s computation overstates the tax relief less tax

${ }^{26}$ UK income tax rules changed after 2011, with big reductions in the annual and lifetime allowances. This brought many more members within the scope of these taxes, decreasing the income tax subsidy and reducing the proportions of income tax and NIC relief, relative to their pension benefits, for high earners. 
payments received by individuals over their lifetime, see Sutcliffe, $2016^{27}$. Only in a steady state of constant contribution rates, income tax rates, longevity, wage rates, scheme funding and number of members, would the government's use of taxes paid by pensioners in the current year be correct. Finally, HMRC treats the risk premium effect and the lower tax rate in retirement as tax subsidies, despite the contrary view of Mirrlees et al. (2011) and Emmerson $(2014,2016)$. Collectively these three effects mean the HMRC computation of the income tax subsidy is a substantial over-statement of the subsidy.

The government has focussed exclusively on reducing and reforming income tax relief, and made no proposals to change the NIC exemptions for the sponsor or members. There are various differences between income tax and national insurance ${ }^{28}$, and the government's exclusive focus on income tax might be because these differences lead the government to prefer to reduce the total subsidy by changing just income tax. However the government has not put forward any of these differences as a reason for its concentration on reforming just income tax relief.

\section{Conclusions}

This paper is the first study of the net wealth effects of rule changes by a large pension scheme, and builds on Platanakis and Sutcliffe (2016) by incorporating twelve taxes and reliefs into their model of USS. We find that the rule changes led to a net wealth reduction for younger cohorts that is about $20 \%$ smaller than

${ }^{27}$ The existence of tax bands, and the possibility they may change over time, complicates matters. There will be a tax subsidy (tax charge) when the rate of tax relief on contributions is higher (lower) than the tax rate charged on the pension. This occurs when a member has an income tax rate when contributing that is higher (lower) than when they are retired. The computation of these rates is complicated by the presence of income tax bands, which raises the possibility that, when a member's pension contributions are subtracted from their gross income, they drop into a lower income tax band. Their rate of income tax relief is now the weighted average of the income tax bands concerned. Similarly for pensioners, their pension may span income tax bands.

${ }^{28}$ These include differences in their tax thresholds; the self-employed are treated differently for NICs; no NICs are payable after the state pension age; NICs have different tax rates and progressivity from income tax; NICs are not payable on unearned income; NICs have weekly assessment periods, and NICs are also payable by the sponsor. 
their gross wealth reduction. Older members experienced progressively smaller differences between their gross and net wealth reductions, and the wealth of pensioners was unchanged. Due to the rule changes the tax subsidy to the sponsor dropped by $£ 0.9 \mathrm{bn}$. , and to members by $£ 1.96 \mathrm{bn}$, which increased government wealth by $f 2.86 \mathrm{bn}$. Although the rule changes made joining USS less attractive by about $£ 85,000$ both gross and net, it remained attractive. The expected lifetime increases in net (gross) wealth for the two youngest age cohorts from joining the pre-2011 final salary scheme and the post-2011 CARE section were $£ 181,000(£ 133,000)$ and $£ 98,000(£ 46,000)$ respectively.

We also conducted a life cycle analysis of the individual components of the tax and NIC subsidy received by members of the post-2011 CARE section and the pre-2011 final salary scheme. Relative to a TEE tax system, the total government subsidy is roughly $£ 65,700$ per head for the CARE section, and $£ 71,400$ for the pre-2011 final salary scheme; while the total subsidy to just members is $£ 46,500$ members for the CARE section, and $£ 47,600$ for the pre-2011 final salary scheme. About $60 \%$ of these subsidies is NIC relief (of which $19 \%$ to $28 \%$ is due to salary sacrifice), split equally between the members and the sponsor; with just $40 \%$ of the total subsidy taking the form of income tax relief. Since USS members have above average salaries, the absolute size of their tax subsidy per person is higher than the national average, although their income tax subsidy as a proportion of their benefits is likely to be higher than the national average. This is because USS is likely to have an above proportion of members subject to a lower tax rate in retirement. So the USS results probably overstate the relative importance of the income tax subsidy for UK DB schemes at $40 \%{ }^{29}$. In contrast, rather than an income tax subsidy of below $40 \%, \mathrm{HMRC}$ have estimated the UK income tax subsidy at $60 \%$ of the total tax and NIC subsidy for 2011-12, (HMRC, 2016). If lower tax rates in retirement and the risk premium effect of EET are deemed not to be a tax subsidy, the tax subsidy to members largely disappears.

29 In $201078 \%$ of UK non-state pensions were DB (Levy, 2012), while the taxation of DC schemes is very similar to that of DB schemes; so this conclusion probably applies to pension schemes in aggregate. 
The government proposals for reducing and reforming the pensions tax subsidy focus entirely on the income tax subsidy to members, and completely ignore the elephant in the room, which is the NIC subsidy that is at least $50 \%$ larger than the income tax subsidy. This concentration on the income tax subsidy may be because HMRC substantially overestimates the relative size of the income tax subsidy. We also argue that the government claim of two thirds of the subsidy going to high earners does not apply to income tax relief, and that the tax and NIC subsidies, as a proportion of pension benefits, decline for high earners.

\section{References}

Adam, S. and Waters, T. (2018) Options for Raising Taxes. In IFS Green Budget: October 2018, edited by C. Emmerson, C. Farquharson and P. Johnson, Institute for Fiscal Studies, pp. 153-193.

Beetsma, R., Lekniute, Z. and Ponds, E. (2014) Reforming American Public Sector Pension Plans: Truths and Consequences, Rotman International Journal of Pension Management, vol. 7, no. 2, Fall, pp. 66-74.

Blake, D. (2003) Pension Schemes and Pension Funds in the United Kingdom, Second edition, Oxford University Press. Board, J.L.G. and Sutcliffe, C.M.S. (2007) Joined-Up Pensions Policy in the UK: An Asset Liability Model for Simultaneously Determining the Asset Allocation and Contribution Rate, Handbook of Asset and Liability Management, vol. 2, edited by S.A. Zenios and W.T. Ziemba, North Holland Handbooks in Finance, Elsevier Science B.V., pp. 1029-1067.

Chapman, R.J., Gordon, T.J. and Speed, C.A. (2001) Pensions, Funding and Risk, British Actuarial Journal, vol. 7, no. part 4, no. 33, October, pp. 605-662.

Chen, Z., Pelsser, A. and Ponds, E. (2014) Evaluating the UK and Dutch Defined-Benefit Pension Policies Using the Holistic Balance Sheet Framework, Insurance: Mathematics and Economics, vol. 58, September, pp. 89-102. Cumbo, J. (2017) Lifetime Allowance Curbs Snare Pension Savers, The Financial Times, 21st July 2017.

Curatola, A.P., Trewin, J. and Walters-York, L.M. (2001) Equality or Simplicity: The Income Taxation of Retirement Plan Distributions, Advances in Taxation, vol. 13, pp. 49-68.

Diebold, F.X. and Li, C. (2006) Forecasting the Term of Government Bond Yields, Journal of Econometrics, vol. 130, no. 2, December, pp. 337-364.

Dilnot, A. and Johnson, P. (1993) Tax Expenditures: The Case of Occupational Pensions, Fiscal Studies, vol. 14, no. 1, February, pp. 42-56.

Draper, N., Van Ewijk, C., Lever, M. and Mehlkopf, R. (2014) Stochastic Generational Accounting Applied to Reforms of Dutch Occupational Pensions, De Economist, vol. 162, no. 3, September, pp. 287-307.

Emmerson, C. (2014) Taxation of Private Pensions. In The Green Budget 2014, edited by C. Emmerson, P. Johnson and H. Miller, Institute for Fiscal Studies, 2014, pp. 221-239. 
Emmerson, C. (2016) Taxation of Private Pensions in the UK, CESifo DICE Report, vol. 14, no. 1, Spring, pp. 10-13.

Emmerson, C. and Johnson, P. (2016) The Taxation of Private Pensions in the UK, ARC Centre of Excellence in Population Ageing Research, working paper 2016/10.

Emmerson, C, and Johnson, P. (2018) The Taxation of Pensions in the United Kingdom, In The Taxation of Pensions, edited by R. Holzmann and J. Piggott, The MIT Press, pp. 235-256.

Hills, J. (2005) Tax Reliefs and Incentives: Are We Getting Value for Money? Pension Policy Institute Annual General Meeting.

Hoevenaars, P.M.M. (2009) Pricing Risk in Corporate Pension Plans: Understanding the Real Pension Deal, Rotman International Journal of Pension Management, vol. 2, no. 1, Spring, pp. 56-62.

Hoevenaars, P.M.M. (2011) Pricing Embedded Options in Value-based Asset Liability Management. In The Oxford Handbook of Quantitative Asset Management, edited by B. Scherer and K. Winston, Oxford University Press, 2011, pp. 449-469.

Hoevenaars, P.M.M., Kocken, T. and Ponds, E. (2009) Pricing Risk in Corporate Pension Plans: Understanding the Real Pension Deal, Rotman International Journal of Pension Management, vol. 2, no. 1, Spring, pp. 56-63.

Hoevenaars, P.M.M. and Ponds, E.H.M. (2007) Inter-generational Value Transfers Within an Industry-wide Pension Fund: A Value-based ALM Analysis. In Costs and Benefits of Collective Pension Systems, edited by O.W. Steenbeck and S.G. Van der Lecq, Springer, pp. 95-117.

Hoevenaars, P.M.M. and Ponds, E.H.M. (2008) Valuation of Inter-generational Transfers in Funded Collective Pension Schemes, Insurance: Mathematics and Economics, vol. 42, no. 2, April, pp. 578-593.

Johnson, M. (2014) Retirement Saving Incentives: The End of Tax Relief and a New Beginning, Centre for Policy Studies, April, 22 pages. http://www.cps.org.uk/publications/reports/retirement-savings-incentives/

Knox, D.M. (1990) The Taxation Support of Occupational Pensions: A Long-Term View, Fiscal Studies, vol. 11, no. 4, November, pp. 29-43.

Levy, S. (2012) Pensions in the National Accounts - A Fuller Picture of the UK's Funded and Unfunded Pension Obligations, Pensions Analysis Unit, Office for National Statistics, April, 23 pages.

Lekniute, Z., Beetsma, R. and Ponds, E. (forthcoming) A Value-based Assessment of Alternative US State Pension Plans?, Journal of Pension Economics and Finance, 41 pages.

Mirrlees, J. et al. (2011) Tax By Design: The Mirrlees Review, Oxford University Press and Institute for Fiscal Studies. Nelson, C.R. and Siegel, A.F. (1987) Parsimonious Modelling of Yield Curve, Journal of Business, vol. 60, pp. 473-489. Pickard, J. Houlder, V. and Parker, G. (2016) Tories Fear Wrath of Middle England, The Financial Times, $4^{\text {th }}$ March.

Platanakis, E. and Sutcliffe, C.M.S. (2016) Pension Scheme Redesign and Wealth Redistribution Between the Members and Sponsor: The USS Rule Change in October 2011, Insurance: Mathematics and Economics, vol. 69, July, pp. 14-28.

Platanakis, E. and Sutcliffe, C. (2015) Asset Liability Modelling and Pension Schemes: the Application of Robust Optimization to USS, European Journal of Finance, vol. 23, no. 4, 2017, pp. 324-352.

Ponds, E.H.M. (2003) Pension Funds and Value-based Generational Accounting, Journal of Pension Economics and Finance, vol. 2, no. 3, November, pp. 295-325. 
Romaniuk, K. (2013) Pension Fund Taxation and Risk-Taking: Should We Switch from EET to the TEE Regime?, Annals of Finance, vol. 9, no. 4, November, pp. 573-588.

Simon, D.S. (1987) Early Retirement and Wealth Transfers in Universities, British Accounting Review, vol. 19, no. 1, pp. 17-33.

Sutcliffe, C.M.S. (2016) Finance and Occupational Pensions: Theories and International Evidence, Palgrave Macmillan. Thurley, D. (2017) Reform of Pension Tax Relief, Briefing Paper no. CBP-07505, October, House of Commons Library.

\section{Documents from Organizations}

European Commission (2001) Report on the Commission Communication on the Elimination of Tax Obstacles to the Cross-border Provision of Occupational Pensions (COM(2001) 214 - C5-0533/2001- 2001/2212(COS))7 November 2001.

http://www.europarl.europa.eu/sides/getDoc.do?pubRef=-//EP//TEXT+REPORT+A5-2001$\underline{0388+0+D O C+X M L+V 0 / / E N \& l a n g u a g e}=I t$

HM Government (2015) Budget 2015: Policy Costings, March, HM Treasury, 67 pages. https://www.gov.uk/government/publications/budget-2015-documents

HM Revenue and Customs (2016) PEN 6 Cost of Registered Pension Scheme Tax Relief, https://www.gov.uk/government/statistics/registered-pension-schemes-cost-of-tax-relief

HM Treasury (2015) Strengthening the Incentive to Save: a Consultation on Pensions Tax Relief, Cm 9102, July. https://www.gov.uk/government/consultations/strengthening-the-incentive-to-save-a-consultation-onpensions-tax-relief

HM Treasury (2016) Reducing the Money Purchase Annual Allowance: Consultation, November. https://www.gov.uk/government/consultations/reducing-the-money-purchase-annual-allowance

HM Treasury (2017) Spring Budget 2017, March, House of Commons 1025 https://www.gov.uk/government/publications/spring-budget-2017-documents Higher Education Statistics Agency (2012) Staff in Higher Education, 2011/12, Table E, HESA. https://www.hesa.ac.uk/data-and-analysis/staff/overviews?breakdown\%5B\%5D=582\&year=10

Higher Education Statistics Agency (2014) Staff in Higher Education, 2012/13, HESA

IRRC Institute (2010) Investment Horizons: Do Managers Do What They Say? IRRC Institute and Mercer, IRRC Institute.

http://irrcinstitute.org/reports/investment-horizons-do-managers-do-what-they-say/

LCP (2017) How is the Tapered Annual Allowance Impacting Pensions?: LCP FTSE 100 Pensions Tax Survey. Lane, Clark and Peacock. https://www.Icp.uk.com/pensions-benefits/publications/ftse-100-pensions-tax-survey/

ONS (2013) Pension Trends - Chapter 9: Pension Scheme Funding and Investment 2013. Office for National Statistics. http://webarchive.nationalarchives.gov.uk/20160105160709/http://ons.gov.uk/ons/rel/pensions/pension -trends/chapter-9--pension-scheme-funding-and-investment--2013-edition/art-pt-chapter-9-2013.html

Office for National Statistics (2014) National Life Tables, United Kingdom 2011-2013, ONS.

OECD (2015) Stocktaking of the Tax Treatment of Funded Private Pension Plans in OECD and EU Countries, OECD. 
www.oecd.org/pensions/Stocktaking-Tax-Treatment-Pensions-OECD-EU.pdf

USS (2011) Report and Accounts for the Year Ended 31 March 2011, Universities Superannuation Scheme.

www.uss.co.uk/ /media/document-libraries/uss/how-uss-is-run/reports-and-

accounts/reportaccounts2011.pdf

USS (2012) Scheme Funding Report of the Actuarial Valuation as at 31 March 2011.

USS (2014) 2014 Actuarial Valuation: A Consultation on the Proposed Assumptions for the Scheme's Technical Provisions and Recovery Plan, USS, October, 39 pages. 


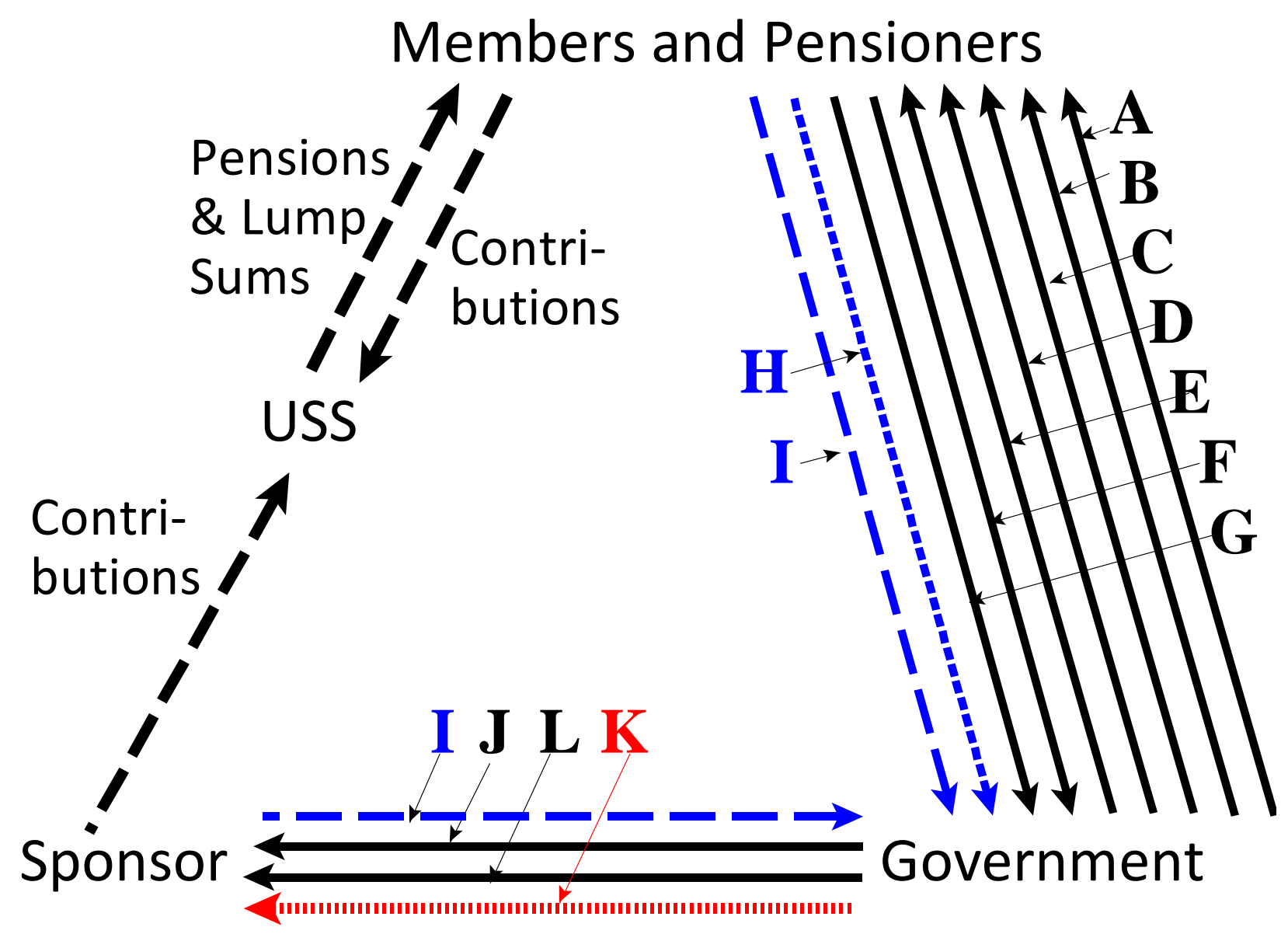

Figure 1: $A$ = Income tax relief on members' pension contributions, $B=$ Salary sacrifice NIC relief - active members, $C=$ Income tax free lump sum, $D=$ Members' NIC exemption for sponsor's pension contributions, $\mathrm{E}=$ Members' income tax relief on the sponsor's pension contributions, $\mathrm{F}$ = Lifetime allowance income taxation, $\mathrm{G}=$ Annual allowance income taxation, $\mathrm{H}=$ Income tax paid on pension payments, I = Stamp duty and dividend tax, $\mathrm{J}=$ Salary sacrifice NIC relief - sponsor, $\mathrm{K}$ = Corporation tax credit, $\mathrm{L}=$ Employer's NIC relief on sponsor's pension contributions. 


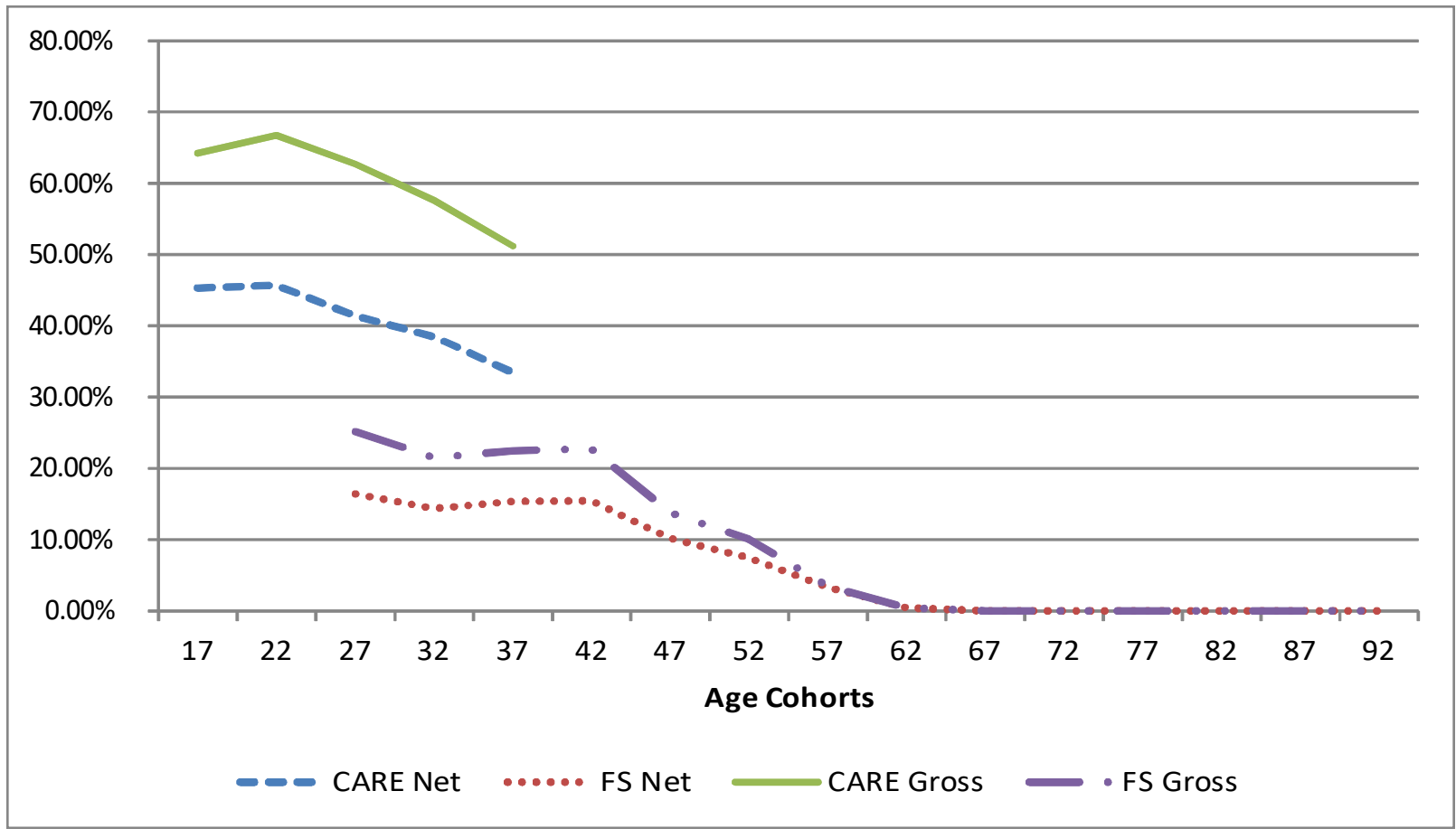

Figure 2: Gross and Net Percentage Drop in the Mean NPV in 2011 of Pension Cash Flows (2011 to 2065) for Each Age Cohort Due to the 2011 Rule Changes 


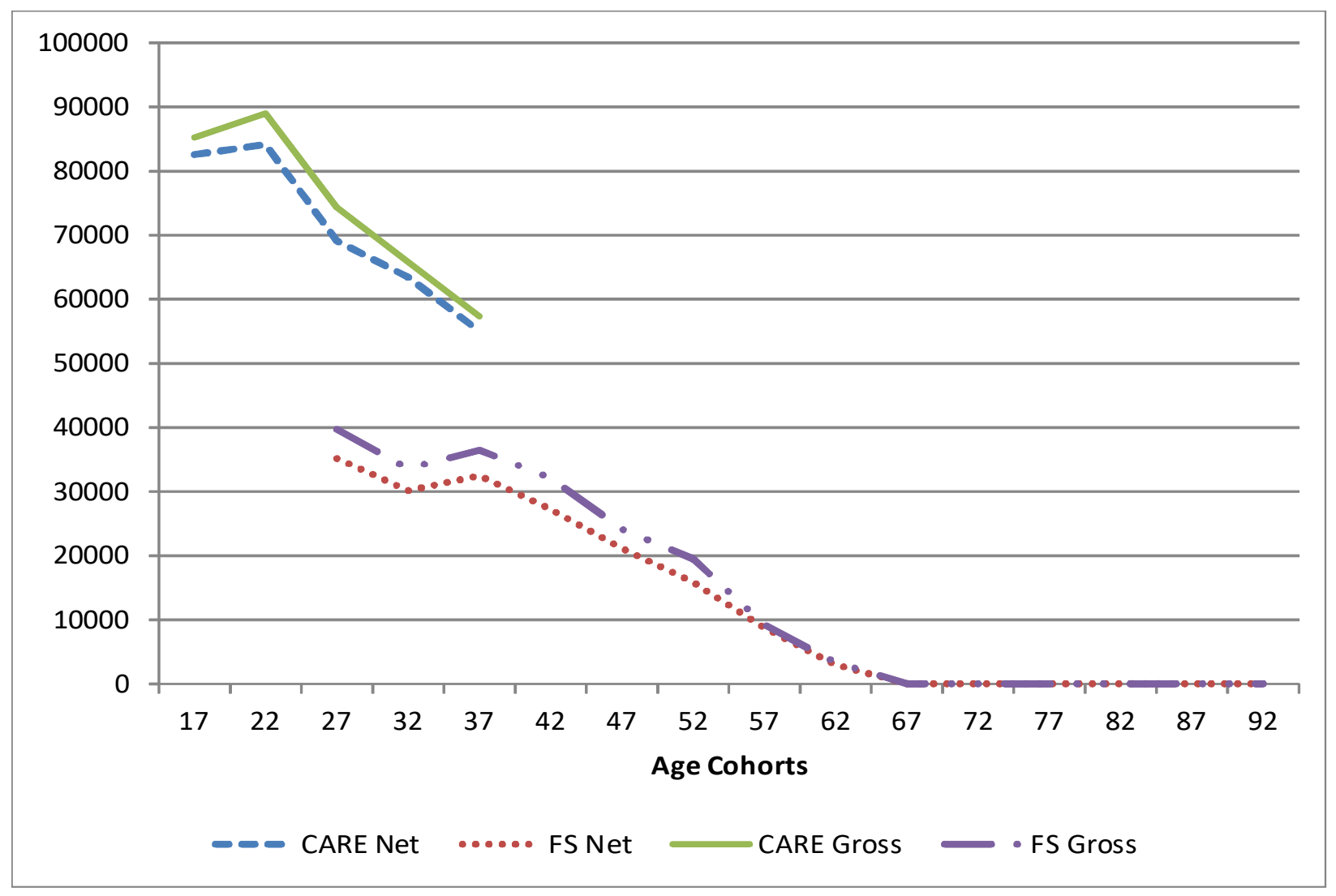

Figure 3: Per Head Gross and Net Drops in the Mean NPV in 2011 of Pension Cash Flows (2011 to 2065) for Each Age Cohort Due to the 2011 Rule Changes 


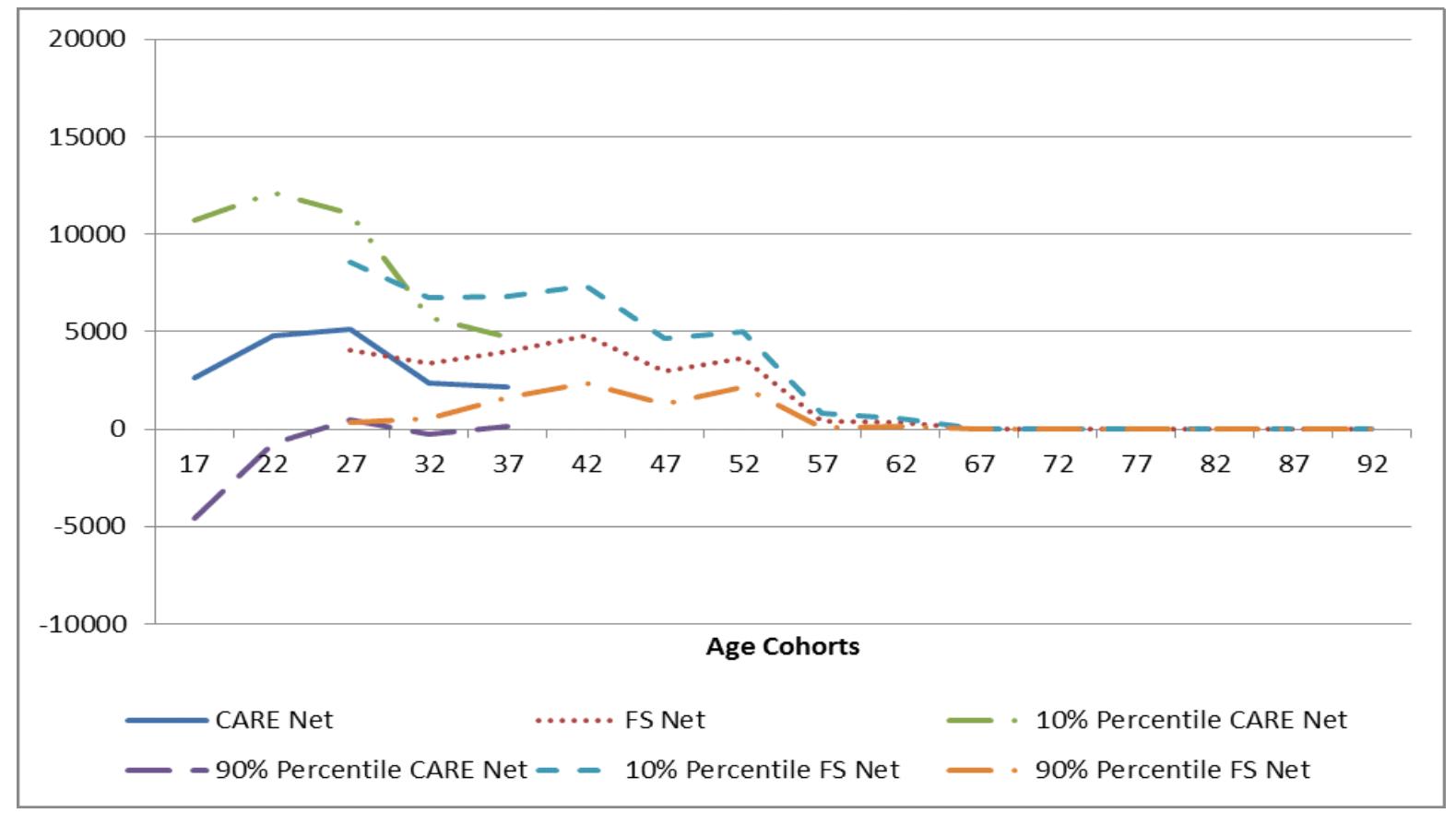

Figure 4: Mean NPV Reduction in $\mathrm{f}$ Per Head (and the $10 \%$ and $90 \%$ percentiles) of the Drop in Net Wealth in 2011 Due to the 2011 Rule Changes 


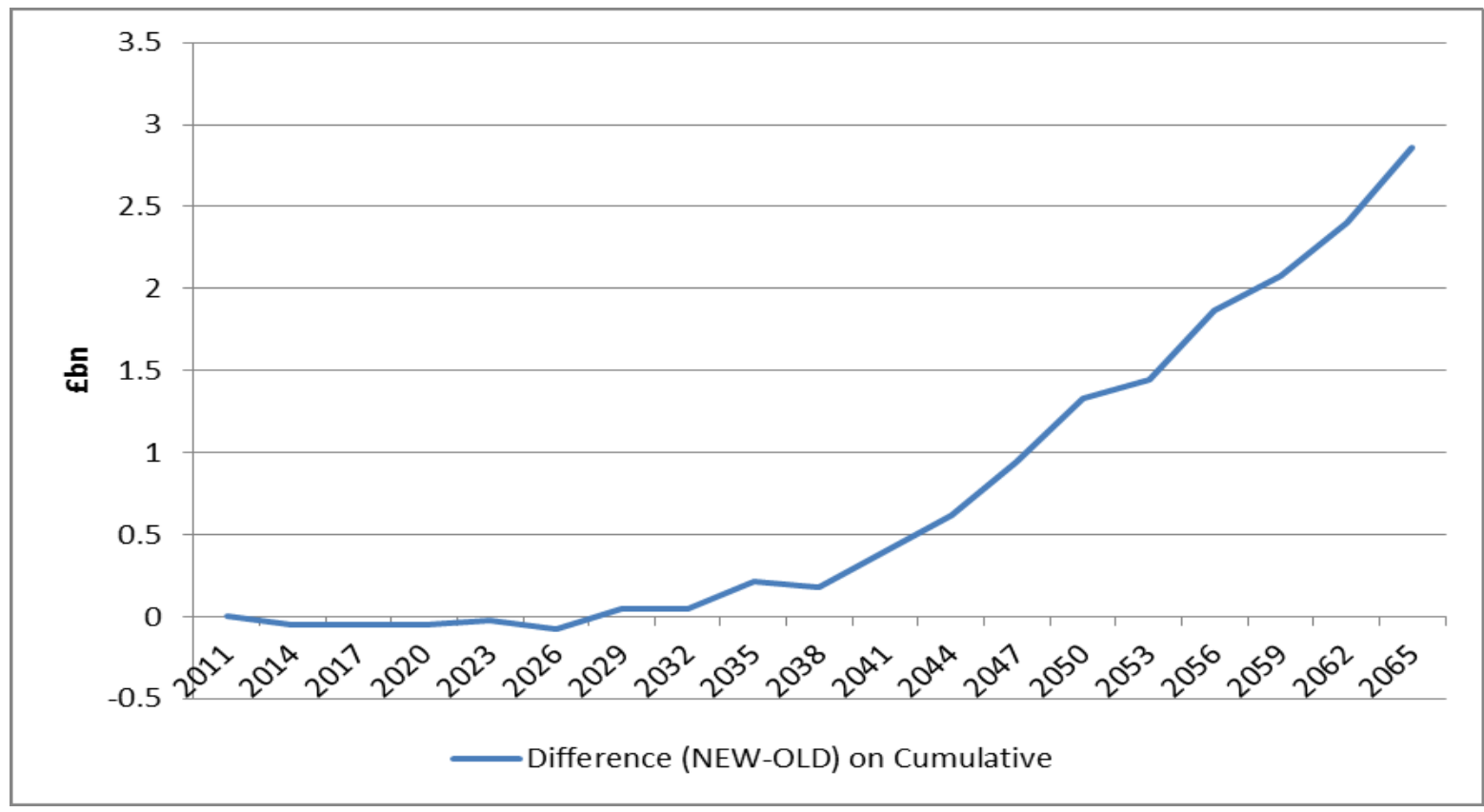

Figure 5: Present Values in 2011 of the Cumulative Change in Government Wealth Due to Changes in Tax and NIC Revenues Caused by the 2011 Rule Changes 


\begin{tabular}{|c|c|c|c|c|}
\hline & Income Tax & Actual EET & Pure EET & Pure TEE \\
\hline \multirow{3}{*}{ Contributions } & Members' contributions to the scheme & Exempt $(A)^{+}$ & Exempt $(\mathrm{A})$ & Taxed $^{*}$ \\
\hline & Sponsor's contributions to the scheme & Exempt (E) & Exempt (E) & Taxed $^{*}$ \\
\hline & Annual allowance excess ${ }^{\neq}$ & $\operatorname{Taxed}^{*}(G)$ & --- & --- \\
\hline \multirow{2}{*}{$\begin{array}{l}\text { Pension Fund } \\
\text { Investment }\end{array}$} & Income of the pension fund & Exempt & Exempt & Exempt \\
\hline & Stamp duty and dividend taxation & Taxed (I) & --- & --- \\
\hline \multirow{3}{*}{ Retirement } & Pensions paid to members & Taxed $^{*}(\mathrm{H})$ & Taxed $^{*}(\mathrm{H})$ & Exempt \\
\hline & Tax free lump sum & $\operatorname{Relief}^{*}(C)$ & --- & --- \\
\hline & Lifetime allowance excess & Taxed $^{*}(F)$ & --- & --- \\
\hline
\end{tabular}

* Taxed at the member's marginal income tax rate, which may be different when contributing and drawing a pension.

† The letters in brackets are those allocated to identify the 12 taxes and reliefs in Figure 1 and the related text. ¥ The UK exceptions to a pure EET system are in italics.

TABLE 1: Summary of the Actual and Pure EET Tax Systems, and the Pure TEE System

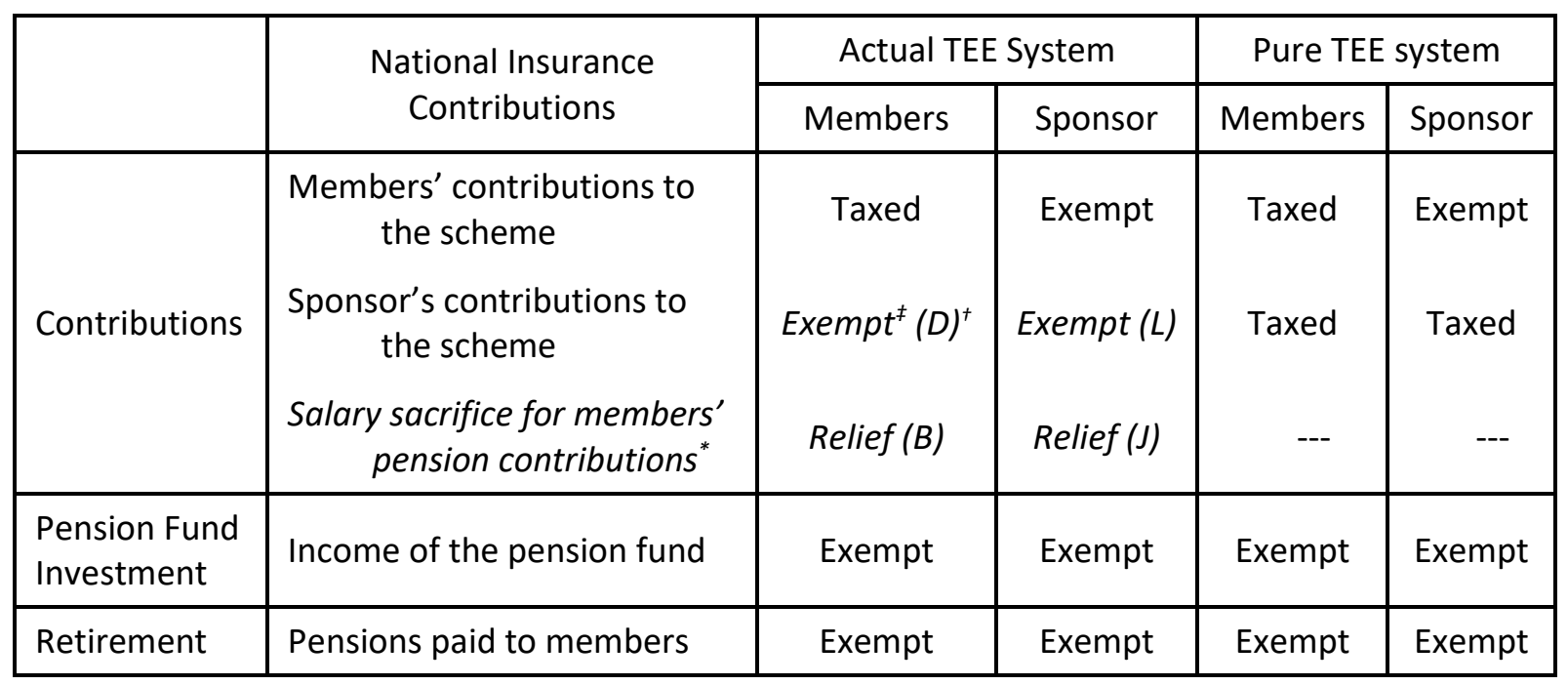

\footnotetext{
* This is relief from paying NICs on that portion of a member's salary used to make pension contributions.

† The letters in brackets are those allocated to identify the 12 taxes and reliefs in Figure 1 and the related text. ¥ The UK exceptions to a pure TEE system are in italics.
}

TABLE 2: Members' and Sponsor's NICs for the Actual and Pure TEE Systems 


\begin{tabular}{|c|c|c|c|c|}
\hline \multirow{2}{*}{ f per Head } & \multicolumn{2}{|c|}{ CARE Section } & \multicolumn{2}{|c|}{ Final Salary } \\
\hline & 17 & 22 & 17 & 22 \\
\hline \multicolumn{5}{|l|}{ Pure TEE Tax paid } \\
\hline Tax on members' contributions (A) & 12,340 & 13,168 & 10,256 & 10,561 \\
\hline Tax on the sponsor's contributions (E) & 29,807 & 31,555 & 34,732 & 35,593 \\
\hline Less the increase in funding - member contributions (TXM) & -825 & -890 & 601 & 628 \\
\hline Less the increase in funding - sponsor contributions (TXS) & $-2,011$ & $-2,151$ & 1,937 & 2,012 \\
\hline Total tax paid & 39,311 & 41,682 & 47,526 & 48,794 \\
\hline \multicolumn{5}{|l|}{ Actual EET Tax paid } \\
\hline Stamp duty and dividends (I) & 1,964 & 2,409 & 1,951 & 2,418 \\
\hline Tax on members' pensions $(\mathrm{H})^{*}$ & 11,705 & 11,870 & 20,531 & 20,812 \\
\hline Total tax paid & 13,669 & 14,279 & 22,482 & 23,230 \\
\hline Tax subsidy to members & 25,642 & 27,403 & 25,044 & 25,564 \\
\hline \multicolumn{5}{|c|}{ Exclusion of Two EET Tax Reliefs } \\
\hline Investment return > discount rate (risk premium) & 10,108 & 14,000 & 5,411 & 11,747 \\
\hline Lower income tax rate in retirement & 5,037 & 5,108 & 6,642 & 6,733 \\
\hline Total of these two tax reliefs & 15,145 & 19,108 & 12,053 & 18,480 \\
\hline Tax subsidy excluding these two reliefs ${ }^{\dagger}$ & 10,497 & 8,295 & 12,991 & 7,084 \\
\hline
\end{tabular}

* The tax paid by members $(\mathrm{H})$ allows for lump sum tax relief.

† Risk premium and lower tax rate in retirement.

TABLE 3: Present Values in $f$ Per Head of Tax Payments for the Average Member for the Actual EET System and a Pure TEE System 


\begin{tabular}{|c|c|c|c|c|}
\hline \multirow{2}{*}{ f per Head } & \multicolumn{2}{|c|}{ CARE Section } & \multicolumn{2}{|c|}{ Final Salary } \\
\hline & 17 & 22 & 17 & 22 \\
\hline \multicolumn{5}{|l|}{ Members NIC Reliefs } \\
\hline Salary sacrifice on members' NICs (B) & 5,211 & 5,557 & 4,353 & 4,477 \\
\hline NICs on the sponsor's pension contributions (D) & 13,970 & 14,778 & 16,399 & 16,793 \\
\hline Increase in funding. Salary sacrifice on members' contributions (SSM) & -340 & -367 & 248 & 259 \\
\hline Increase in funding. NICs on sponsor's pension contributions (NRM) & -378 & -408 & 275 & 288 \\
\hline NICs on the increase in the cost-neutral salary under TEE & 782 & 1,113 & 332 & 896 \\
\hline Total NIC relief to members & 19,245 & 20,673 & 21,607 & 22,713 \\
\hline \multicolumn{5}{|l|}{ Sponsor's NIC Reliefs } \\
\hline Effect of salary sacrifice on the sponsor's NICs (J) & 5,317 & 5,670 & 4,442 & 4,568 \\
\hline NICs on the sponsor's pension contributions (L) & 14,255 & 15,080 & 16,734 & 17,136 \\
\hline Increase in funding. Salary sacrifice on members' contributions (SSS) & -847 & -906 & 816 & 847 \\
\hline Increase in funding. NICs on sponsor's pension contributions (NRS) & -941 & $-1,006$ & 906 & 941 \\
\hline NICs on the increase in the cost-neutral salary under TEE & 774 & 1,101 & 329 & 886 \\
\hline Total NIC relief to sponsor & 18,558 & 19,939 & 23,227 & 24,378 \\
\hline
\end{tabular}

TABLE 4: Present Values in $f$ Per Head of the Average Members' and the Sponsor's NIC Reliefs Under a Pure TEE System

\begin{tabular}{|l|c|c|c|c|}
\hline \multirow{2}{*}{ f per Head } & \multicolumn{2}{c|}{ CARE Section } & \multicolumn{2}{c|}{ Final Salary } \\
\cline { 2 - 5 } & 17 & 22 & 17 & 22 \\
\hline Income tax subsidy to members from Table 3 & 25,642 & 27,403 & 25,403 & 25,564 \\
\hline NIC subsidy to members from Table 4 & 19,245 & 20,673 & 21,607 & 22,713 \\
\hline Total subsidy to members & 44,887 & 48,076 & 47,010 & 48,277 \\
\hline NIC subsidy to the sponsor from Table 4 & 18,558 & 19,939 & 23,227 & 24,378 \\
\hline Total subsidy to members and sponsor & 63,445 & 68,015 & 70,237 & 72,655 \\
\hline
\end{tabular}

TABLE 5: Summary of the Present Values in $f$ Per Head of the Income Tax and NIC Subsidies to Members and the Sponsor 


\section{Appendix 1: Twelve Tax Effects}

We incorporate these twelve UK tax effects into the P\&S model, which involves extending the P\&S model to include the UK government as a third stakeholder, in addition to the sponsor and the 50 groups of members. We now outline these tax effects.

(A) The total income tax relief on pension contributions received by active members of age cohort $i$ at time $t\left(T_{c i t}\right)$ is given by:-

$$
\mathrm{T}_{\text {cit }}=\mathrm{t}_{\mathrm{ait}} \cdot \mathrm{CR}_{\mathrm{t}} \cdot \mathrm{S}_{\mathrm{it}}
$$

where $t_{\text {ait }}$ is the income tax rate for active members of age cohort $i$ at time $t, C R_{t}$ is the active member contribution rate at time $t$, and $S_{i t}$ is the aggregate gross salary of the active members of age cohort $i$ at time $t$. This income tax relief leads to an increase in the wealth of members, and a loss of tax revenue by the government.

(B) Salary sacrifice for pensions means that both the member and sponsor avoid paying NICs on the member's salary used to make pension contributions. The reduction in NICs for active members in age cohort $i$ at time $t\left(N^{m} i t\right)$ is:-

$$
\mathrm{N}^{\mathrm{m}} \text { it }=\mathrm{n}^{\mathrm{m}}{ }_{\mathrm{it}} \cdot \mathrm{CR}_{\mathrm{t}} \cdot \mathrm{S}_{\mathrm{it}} \cdot \mathrm{p}_{\mathrm{t}}
$$

where $n^{m}{ }_{i t}$ is the NIC rate for members of age cohort $i$ at time $t$, and $p_{t}$ is the proportion of member pension contributions at time $t$ subject to salary sacrifice. This increases member wealth at a cost to the government.

(C) Pensioners can take an income tax free lump sum on retirement. P\&S assume each pensioner takes a tax free lump sum of three times their annual pension, which is the USS default. Therefore at retirement each final salary pensioner receives income tax relief $\left(T^{F S}\right.$ Ist $)$ of:-

$$
\mathrm{T}^{\mathrm{FS}}{ }_{\text {Ist }}=3 \mathrm{t}^{\mathrm{FS}}{ }_{\text {pit }} . \mathrm{P}^{\mathrm{FS}}{ }_{\text {it }}
$$

where $t^{F S}$ pit is the income tax rate for final salary pensioners of age cohort $i$ at time $t$ (the year of retirement), and $P^{F S}{ }_{i t}$ is the total gross pension payment received by final salary pensioners in age cohort $i$ at time $t$. This income tax relief increases member wealth and reduces the government's tax receipts. Similarly, the income tax relief on tax free lump sums received by CARE pensioners in age cohort $i\left(T^{C A R E} E_{\text {Ist }}\right)$ is:-

$$
\mathrm{T}^{\mathrm{CARE}_{\text {Ist }}}=3 \mathrm{t}^{\mathrm{CARE}}{ }_{\text {pit. }} \cdot \mathrm{P}^{\mathrm{CARE}}{ }_{\text {it }}
$$

where $t^{\text {CARE }}$ pit is the income tax rate for CARE pensioners of age cohort $i$ at time $t$, and $P^{\text {CARE }_{i t}}$ is the total gross pension payment received by CARE pensioners in age cohort $i$ at time $t$. 
(D) Members are exempt from paying NICs on the sponsor's pension contributions. This relief $\left(N S^{m}{ }_{i t}\right)$ is:-

$$
N S^{m_{i t}}=n^{m_{i t}} \cdot C^{s}{ }_{t} \cdot S_{i t}
$$

which increases member wealth and reduces government revenues.

(E) Members are exempt from paying income tax on the sponsor's contributions to their pension. This income tax relief $\left(\mathrm{TS}_{\text {cit }}\right)$ is:-

$$
\mathrm{TS}_{\mathrm{cit}}=\mathrm{t}_{\text {ait }} \cdot \mathrm{CR}_{\mathrm{t}}^{\mathrm{s}} \cdot \mathrm{S}_{\mathrm{it}}
$$

and increases the wealth of members and reduces government tax revenues.

(F) The income tax paid by age cohort $i$ when they retire at time $t$ for exceeding the lifetime allowance $\left(T_{\text {lit }}\right)$ is given by:-

$$
T_{\text {lit }}=t_{\text {lit. }} L_{\text {it }}
$$

where $L_{i t}$ is the value of the accrued benefits of age cohort $i$ when they retire at time $t$, and $t_{\text {lit }}$ is a tax factor for age cohort $i$ at time $t$ that gives the relationship at time $t$ between the value of the $i^{\text {th }}$ cohort's accrued benefits and their income tax charge for exceeding the lifetime allowance. This income tax on the accrued pension benefits reduces member wealth, and generates a tax receipt for the government.

(G) The income tax paid at time $t$ by active members of age cohort $i$ for exceeding the annual allowance $\left(T_{b i t}\right)$ is given by :-

$$
\mathrm{T}_{\mathrm{bit}}=\mathrm{t}_{\mathrm{bit}} \cdot \Delta \mathrm{A}_{\mathrm{it}}
$$

where $t_{\text {bit }}$ is the tax factor giving the proportion of the increase in pension benefits for age cohort $i$ at time $t$ that is charged as income tax, and $\Delta A_{i t}$ is the increase in the accrued benefits of age cohort $i$ at time $t$. This tax reduces the wealth of members and increases government tax revenues.

(H) The total income tax on final salary pension payments to age cohort $i$ at time $t\left(T^{F S}\right.$ pit $)$ is given by:-

$$
\mathrm{T}^{\mathrm{FS}}{ }_{\text {pit }}=\mathrm{t}^{\mathrm{FS}}{ }_{\text {pit }} \cdot \mathrm{P}^{\mathrm{FS}}{ }_{\text {it }}
$$

The wealth of final salary pensioners is reduced by the income tax they must pay on their pensions, which increases government tax revenues. Similarly, the income tax paid by CARE pensioners in age cohort $\mathrm{i}$ ( $\left.T^{\text {CARE }}{ }_{p i t}\right)$ is:-

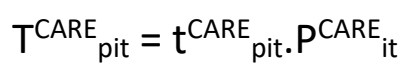

which reduces member wealth, and increases government wealth. 
(I) Under a pure EET income tax system the gains from investing the pension fund are tax exempt, but this is not the case in the UK. The pension fund pays stamp duty on UK equity and property purchases, and does not receive a tax credit for the corporation tax paid by UK companies from which the pension fund receives dividends. Pension funds pay stamp duty of $0.5 \%$ of the value of a trade when they purchase UK equities. They also pays stamp duty when they purchase property in the UK. This tax charge for dividends and stamp duty $\left(T_{s t}\right)$ at time $t$ paid by the pension fund is given by:-

$$
T_{s t}=t_{s t} . l_{t}+0.005 E_{t}+T_{r t}
$$

where $t_{s t}$ is the proportion of investment income paid in tax at time $t$, and $I_{t}$ is the pension fund's net dividend income from UK companies at time $t, E_{t}$ is the value of UK equities purchased by the pension fund during period $t$, and $T_{r t}$ is the stamp duty paid on UK property purchases in period $t$. The stamp duty and the lack of dividend tax credits increase government tax receipts and reduces the size of the pension fund. Since DB benefits are fixed, those responsible for funding the scheme must make additional contributions. For the pre-2011 scheme this is the sponsor; but with the introduction of cap-and-share in 2011, this is $65 \%$ for the sponsor and $35 \%$ for the active members. The extra contributions, and resulting tax relief, to compensate the scheme for these taxes are already included in the model; but the cost of these taxes needs to be allocated between the sponsor and members.

(J) Under salary sacrifice the sponsor does not pay NICs on that portion of members' salary which members use to make pension contributions. For those members in age cohort $i$ of active members at time $t\left(N^{s}{ }_{i t}\right)$ who have opted into salary sacrifice it is:-

$$
\mathrm{N}^{\mathrm{s}}{ }_{\mathrm{it}}=\mathrm{n}^{\mathrm{s}}{ }_{\mathrm{it}} \cdot \mathrm{CR}_{\mathrm{t}} \cdot \mathrm{S}_{\mathrm{it}} \cdot \mathrm{p}_{\mathrm{t}}
$$

where $n_{i t}^{s}$ is the sponsor's NIC rate. This increases sponsor wealth, and reduces the government's NIC receipts.

(K) For corporations their pension contributions are a charge against profits, and so they receive a tax credit at time $t\left(T_{z t}\right)$ of:-

$$
\mathrm{T}_{\mathrm{zt}}=\mathrm{CR}_{\mathrm{t}}^{\mathrm{s}} \cdot \mathrm{t}_{\mathrm{zt}} \cdot \sum \mathrm{S}_{\mathrm{it}}
$$

where $C R^{s}{ }_{t}$ is the sponsor's contribution rate at time $t, t_{z t}$ is the corporation tax rate at time $t$, and the summation of salaries at time $t$ is across all age cohorts. This tax relief reduces government tax revenue, and increase the wealth of the sponsor. Corporation tax paying companies receive corporation tax relief on both the wages they pay and their pension contributions, while tax exempt institutions such as USS do not receive relief from corporation tax on wages or pension contributions. If the rule change is not cost neutral for the sponsor, the sponsor's corporation tax payments will change. 
(L) Sponsors are exempt from paying employer NICs on their pension contributions. In the following equation $\left(N S^{s}{ }_{i t}\right)$ is the NICs the sponsor has been exempted from paying on their pension contribution in period $t$ for cohort $i^{30}$.

$$
N S^{s}{ }_{i t}=n^{s}{ }_{i t} \cdot C R^{s} \cdot S_{i t}
$$

This relief increases sponsor wealth and reduces government revenues.

\section{Appendix 2 - Estimation of Model Parameters}

The UK tax system is highly complex, and we model only the twelve main tax effects identified above in Figure 1. To quantify these tax effects the parameters in equations (A1) to (A12) must be estimated, which is a challenging task. Therefore the estimated net wealth effects are subject to considerable estimation error. Equations (A1) to (A12) involve 20 parameters. Seven of these parameters are available each year for each age cohort from the P\&S model - total gross salaries $\left(S_{i t}\right)$, total pension payments $\left(P^{F S}\right.$ it and $\left.P^{\text {CARE }}{ }_{i t}\right)$, accrued benefits $\left(L_{i t}\right)$, the members' contribution rate $\left(C R_{t}\right)$, the sponsor's contribution rate $\left(C R_{t}^{s}\right)$ and the increase in accrued liabilities $\left(\Delta A_{i t}\right)$. This leaves 13 parameters to be estimated - three income tax rates $\left(t_{\text {ait }}, t_{\text {pit }}^{F S}\right.$ and $\left.t_{\text {pit }}^{\text {CARE }}\right)$, the rate of corporation tax $\left(t_{z t}\right)$, three tax factors $\left(t_{\text {lit }}, t_{b i t}\right.$, and $\left.t_{s t}\right)$, the NIC rates for members $\left(n^{m}{ }_{i t}\right)$ and the sponsor $\left(n^{s}{ }_{i t}\right)$, UK equity turnover $\left(E_{t}\right)$, stamp duty on UK property $\left(T_{r t}\right)$, the annual value of UK dividend income $\left(I_{t}\right)$ for USS, and the proportion of member contributions subject to salary sacrifice $\left(p_{t}\right)$.

What is needed for the tax effects, except that for UK dividend income, is the tax rate for each age cohort. While members of the same cohort are the same age, their taxable incomes differ, potentially placing them in different tax bands. In 2011 income tax rates were $20 \%$ for gross incomes between $£ 6,475$ and $£ 43,875,40 \%$ for gross incomes between $£ 43,875$ and $£ 150,000$, and $50 \%$ for gross incomes higher than $£ 150,000$.

(1) Active Members - Marginal Income Tax Rate ( $\left.t_{\text {ait }}\right)$. Table E of HESA (2012) has the income distribution for each age cohort of full-time academic staff in 2012-3 divided into six income bands, where the division between the middle two bands is a gross income of $£ 42,055$ per year. For each age cohort we compute the total gross income for the three income bands above $f 42,055\left(Y^{a}{ }_{40 t}\right)$ which we treat as approximately

${ }^{30}$ NICs are a deductible expense for companies when computing corporation tax, which reduces the net cost to the government of this NIC relief. As the corporation tax rate in 2011 was $26 \%$, the net saving for corporate sponsors is $74 \%$ of the reduction in NIC payments. However, universities are exempt from paying corporation tax, so this adjustment does not apply to USS. 
equal to the higher rate income tax threshold of $£ 43,875$, and the three lower income bands $\left(Y^{a} 20 t\right)^{31}$. The marginal income tax rate for the $i^{\text {th }}$ age cohort at time $t\left(t_{\text {ait }}\right)$ assuming that all incomes change by the same percentage is:-

$$
t_{\text {ait }}=\left(0.4 Y^{a_{40 t}}+0.2 Y^{a}{ }_{20 t}\right) /\left(T Y^{a_{i t}}\right)
$$

where $T Y^{a}{ }_{i t}$ is the total gross income of cohort $i$ of active members at time $t, Y^{a}{ }_{20 t}$ is the total gross income of active members between the income tax free allowance of $£ 6,475$ and the $40 \%$ income tax threshold for both the final salary and CARE members at time $t$, and $Y^{a}{ }_{40 t}$ is their total gross income above the $40 \%$ income tax threshold at time $t$. The values of $Y^{a}{ }_{40 t}, Y^{a}{ }_{20 t}$ and $T Y^{a}{ }_{i t}$ for each period are available from the P\&S model. We assume that the same income tax rates apply in future years, with the income tax thresholds rising with gross incomes so that $t_{\text {ait }}$ remains constant over time.

(2) Pensioners - Marginal Income Tax Rates ( $t^{\text {FS }}$ pit and $\left.t^{\text {CARE }}{ }_{\text {pit }}\right)$. For those receiving a final salary pension we use the income distribution data for the 61 to 65 and over 65 age cohorts in Table E of HESA (2012) to estimate the income distribution of the salaries on which their pensions are based. This enables us to compute the total gross income of final salary pensioners in the $i^{\text {th }}$ cohort at time $t$ above the $40 \%$ income tax threshold $\left(Y^{p F S}{ }_{40 t}\right)$, and between the personal allowance for final salary pensioners of $£ 9,500$ in 2011 and the $40 \%$ income tax threshold ( $Y^{p F S} 20 t$ ). Equation (A14a) gives the marginal income tax rate for the $i^{\text {th }}$ age cohort at time $t$ of final salary pensioners $\left(t^{F S}\right.$ pit $)$ :-

$$
\mathrm{t}^{\mathrm{FS}} \mathrm{pit}=\left(0.4 \mathrm{Y}^{\mathrm{pFS}} 40 \mathrm{t}+0.2 \mathrm{Y}^{\mathrm{pFS}}{ }_{20 \mathrm{t}}\right) / \mathrm{TY}^{\mathrm{pFS}}{ }_{\text {it }}
$$

where $T Y^{p F s}{ }_{i t}$ is the total gross income of the $i^{\text {th }}$ cohort of final salary pensioners at time $t$. For the CARE section we use the income distributions for all ten of the age cohorts in Table E of HESA (2012), along with salary increases and inflation data from P\&S, to estimate the distribution of the CARE pensions. Similarly to final salary pensioners, the marginal income tax rate for CARE pensioners in the $i^{\text {th }}$ age cohort at time $t$ $\left(t^{\text {CARE }}{ }_{\text {pit }}\right)$ is:-

$$
t^{\text {CARE }}{ }_{\text {pit }}=\left(0.4 Y^{\text {pCARE }}{ }_{40 t}+0.2 Y^{\text {pCARE }}{ }_{20 t}\right) / \text { TY }^{\text {pCARE }_{i t}}
$$

where $T Y^{\text {pCARE }}$ it is the total gross income of the $i^{\text {th }}$ cohort of CARE pensioners at time $t, Y^{\text {pCARE }}{ }_{40 t}$ is the total gross income of CARE pensioners in the $i^{\text {th }}$ cohort at time $t$ above the $40 \%$ income tax threshold, and $Y^{\text {PCARE }}{ }_{20 t}$ is the total gross income for CARE pensioners in the $i^{\text {th }}$ cohort at time $t$ between the personal allowance of $£ 9,500$ in 2011 and the 40\% income tax threshold. For each final salary and CARE age cohort the annual USS pension is available from the P\&S model. In addition to their USS pension, we assume that final salary and CARE pensioners receive a state pension of $£ 5,300$ gross per year in 2011 , and an estimated

${ }^{31}$ No USS members earn less than the income tax free personal allowance. While a small number of USS members had a gross income over $£ 150,000$ in 2011 , for simplicity we assume the top income tax rate is $40 \%$. 
$£ 2,000$ in additional gross income in 2011 from all other sources. We also assume that the distribution of final salary and CARE pensioner incomes remains constant over time, and that the mean income and income tax bands increase in line with each other, so that the marginal income tax rates ( $t^{\text {FS }}$ pit and $\left.\mathrm{t}^{\mathrm{CARE}}{ }_{\text {pit }}\right)$ are unaltered.

(3) Sponsor's Marginal NIC Rates $\left(n^{s}\right.$ it). In 2011 USS was a contracted-out scheme, and for sponsors the NIC contracted-out rates in 2011 were $9.1 \%$ for gross income between $£ 5,715$ and $£ 40,040$, and $12.8 \%$ for higher gross incomes ${ }^{32}$. The marginal NIC rate paid by the sponsor for the members of cohort $i$ at time $t$ $\left(n^{s}{ }_{i t}\right)$ is:-

$$
\mathrm{n}^{\mathrm{s}}{ }_{\mathrm{it}}=\left(0.128 \mathrm{Y}^{\mathrm{a}}{ }_{40 \mathrm{t}}+0.095 \mathrm{Y}^{\mathrm{a}}{ }_{20 \mathrm{t}}\right) / \mathrm{TY}^{\mathrm{a}}{ }_{\mathrm{it}}
$$

We assume that sponsor NIC thresholds increase over time to allow for rising prices and incomes, while NIC rates for each band remain constant.

(4) Members' Marginal NIC Rates $\left(n^{m}{ }_{i t}\right)$. In 2011 the contracted-out members' NIC rates were $9.4 \%$ for gross income between $£ 5,715$ and $£ 40,040,11 \%$ for gross income between $£ 40,040$ and $£ 43,875$, and $1 \%$ above $£ 43,875^{33}$. We used the income distributions for each age cohort in Table E (HESA, 2012) to compute the marginal NIC rates for each cohort of active members. The marginal NIC rate $\left(\mathrm{n}^{m}{ }_{i t}\right)$ for members of age cohort $i$ at time $t$ is:-

$$
n^{m_{i t}}=\left(0.01 Y^{a}{ }_{40 t}+0.096 Y^{a}{ }_{20 t}\right) / T Y^{a_{i t}}
$$

As for sponsor NICs, we assume NIC thresholds increase over time to allow for rising prices and incomes, while NIC rates for each band remain constant.

(5) Salary Sacrifice $\left(p_{t}\right)$. Salary sacrifice is attractive to the sponsor and virtually all USS members under the state retirement age, and has been widely adopted by UK universities. In the absence of any firm data, given the use by universities of auto-enrolment into salary sacrifice, it is assumed that $90 \%$ of members' contributions are via salary sacrifice $\left(p_{t}\right)$, and that this proportion remains constant over time.

(6) Corporation $\operatorname{Tax}\left(t_{z t}\right)$. In 2011 the rate of corporation tax was $26 \%$, and this is assumed constant over time. As previously explained, given our benchmark, pensions tax relief has no effect on corporation tax payments.

\footnotetext{
${ }^{32}$ For simplicity we use a blended NIC rate of $9.5 \%$ for member incomes between $£ 5,715$ and $£ 43,875$.

${ }^{33}$ For simplicity we use a blended NIC rate of $9.6 \%$ for member incomes between $£ 5,715$ and $£ 43,875$.
} 
(7) Tax Factor for UK Dividends $\left(t_{s t}\right)$. Since the rate of UK corporation tax in 2011 was $26 \%$, the tax rate for net UK dividend income is $t_{s t}=1 /(1-0.26)=35 \%$.

(8) Tax Factor for the Lifetime Allowance $\left(t_{\text {lit }}\right)$. In addition to income tax on their pensions, when they retire pensioners may also have to pay tax of $25 \%$ on the value of their accrued benefits in excess of the lifetime allowance, which was $£ 1.8$ million in 2011 . It has been estimated that "over $96 \%$ of individuals currently approaching retirement have a pension pot worth less than $f 1$ million, so this change will affect only the wealthiest pension savers" (HM Government, 2015). A freedom of information request submitted by Salisbury House Wealth revealed that the tax revenue generated by the lifetime allowance in 2012-13 was f12 million, rising to only $£ 36$ million in 2015-16 (Cumbo, 2017). In 2011 USS represented approximately $1.6 \%$ of the assets of UK occupational pension schemes, but since USS members retire on larger average pensions than almost every other big UK DB scheme, the share of the lifetime allowance tax paid by USS members is assumed to be $2 \%$. This implies that in 2011 USS pensioners paid only $f 1$ million in tax due to exceeding the lifetime allowance. As this sum is very much smaller that the rounding error of the model, all the values of $t_{\text {lit }}$ are set to zero.

(9) Tax Factor for the Annual Allowance ( $\left.t_{b i t}\right)$. If the annual increase in the value of an active member's accrued benefits exceeds the annual allowance, they must pay income tax on the excess ${ }^{34}$. Members who trigger this income tax tend to be the higher paid with many accrued years who receive a substantial pay rise. In 2011 the annual allowance was $£ 255,000$ per year. No separate estimates of the income tax revenue generated from exceeding the annual allowance in 2011 are available, but very few USS members will have exceeded the 2011 annual allowance. So we conclude that the annual income tax charge to USS members for exceeding this allowance $\left(T_{\text {bit }}\right)$ was very small, and $t_{\text {bit }}$ will be set to zero for all values of $i$ and $t$.

(10) UK Dividend Income $\left(I_{t}\right)$. In 2011 USS net UK dividend income was $f 236$ million, which implies a corporation tax payment of $£ 83$ million. In addition, $£ 13$ million of withholding tax was deducted at source in 2011, making a total payment of almost $£ 100$ million. Over the period from 1999 to 2011 USS investment income grew by an average of 3.3\% per year, and the corporation tax payment by USS of $£ 100$ million in 2011 is also assumed to rise by $3.3 \%$ per year.

${ }^{34}$ Active members can choose to have the income tax charges arising from exceeding their annual allowance paid by the scheme, accompanied by a reduction in their accrued benefits. 
(11) UK Equity Turnover ( $\left.E_{t}\right)$. In 2011 USS owned $f 7,154$ million of UK equities. A survey of almost 1,000 institutional investors by the IRRC Institute (2010) found that the average holding period for equities is 1.4 years. This implies the value of UK equities purchased by USS in 2011 was $f 7,154(12 / 17)=£ 5,050$ million. The proportions of USS assets invested in UK equities are available from the fix-mix asset allocation used by $P \& S$, and are used to estimate the annual turnover in UK equities.

(12) Stamp Duty on UK Property $\left(T_{r t}\right)$. This tax payment is minimal because USS used special purpose vehicles to avoid this tax, and so $T_{r t}$ is set to zero.

\section{Appendix 3: Estimation of the Effects of the Changes in USS Funding Over the 2011-65 Period}

To allocate the changes over the 2011-65 period in the funding of the pre-and post 2011 schemes to the various age cohorts, we first compute the present value of the contributions by each cohort $\left(P V M_{i}\right)$ and the sponsor (PVS), where $r_{t}$ is the discount rate for period $t$.

$$
\begin{aligned}
& P V M_{i}=\sum_{t=1}^{n} C R_{t} S_{i t} /\left(1+r_{t}\right)^{t}, \quad \text { where } \mathrm{i}=1 \ldots . \mathrm{m} \text { cohorts } \\
& P V S=\sum_{t=1}^{n} C R_{t}^{S} S_{t} /\left(1+r_{t}\right)^{t}, \quad \text { where } \mathrm{i}=1 \ldots . \mathrm{m} \text { cohorts }
\end{aligned}
$$

Next we allocate the present value of the change in USS funding over the 2011-65 period $(\Delta F)$ between the age cohorts:-

$$
\begin{aligned}
& A M_{i}=\Delta F \times P V M_{i} / \sum_{i=1}^{m}\left(P V M_{i}+P V S\right), \quad \text { where } \mathrm{i}=1 \ldots . \mathrm{m} \text { cohorts } \\
& A S=\Delta F \times P V S / \sum_{i=1}^{m}\left(P V M_{i}+P V S\right), \quad \text { where } \mathrm{i}=1 \ldots . \mathrm{m} \text { cohorts }
\end{aligned}
$$

A. Income Tax ( $A$ and $E)$. The present value of the income tax relief for the members of cohort $i$ on their own contributions due to the change in funding $\left(T X M_{i}\right)$ is:-

$$
T X M_{i}=b_{i} \times A M_{i}, \quad \text { where } \mathrm{i}=1 \ldots . \mathrm{m} \text { cohorts }
$$

where $b_{i}$ is the average tax rate for active members of cohort $i$, i.e. $\sum_{t=1}^{n} t_{a i t}$. The corresponding changes in the tax relief on the sponsor's contributions due to the change in USS funding $\left(\mathrm{TXS}_{\mathrm{i}}\right)$ are:-

$$
T X S_{i}=b_{i} \times A S_{i}, \quad \text { where } \mathrm{i}=1 \ldots . \mathrm{m} \text { cohorts }
$$

B. Salary Sacrifice ( $B$ and $J$ ). The present values of the salary sacrifice relief for members on their NICs due to the change in funding $\left(S S M_{i}\right)$ are:-

$$
S S M_{i}=0.9\left(A M_{i}\right) q_{i}^{m}, \quad \text { where } \mathrm{i}=1 \ldots . \mathrm{m} \text { cohorts }
$$


where $q^{m_{\mathrm{i}}}$ is the average member contribution rate for cohort $i$, i.e. $(1 / n) \sum_{t=1}^{n} n_{i t}^{m}$. The corresponding salary sacrifice effects for the sponsor $\left(\mathrm{SSS}_{\mathrm{i}}\right)$ are:-

$$
S S S_{i}=0.9\left(A S_{i}\right) q_{i}^{S}, \quad \text { where } \mathrm{i}=1 \ldots . \mathrm{m} \text { cohorts }
$$

where $q_{i}^{s}$ is the average sponsor contribution rate for cohort $i$, i.e. $(1 / n) \sum_{t=1}^{n} n_{i t}^{S}$.

C. NICS ( $D$ and $L)$. The present values of the NIC relief for members due to the change in USS funding (NRMi) are:-

$$
N R M_{i}=q_{i}^{m} \times A M_{i}, \quad \text { where } \mathrm{i}=1 \ldots . \mathrm{m} \text { cohorts }
$$

and the corresponding NIC reliefs for the sponsor $\left(N R S_{i}\right)$ are:-

$$
N R S_{i}=q_{i}^{S} \times A S_{i}, \quad \text { where } \mathrm{i}=1 \ldots . \mathrm{m} \text { cohorts }
$$

\section{Appendix 4: Comparison of the EET and TEE Taxation Systems}

Let the rate at which members of an age cohort pay tax on their pension contributions and those made by the sponsor in year $i$ be $x_{i} \%$, and $z \%$ be the tax rate on pension payments received by these members in retirement. It is assumed that upper limits on the tax deductibility of contributions do not apply. The pension scheme's investment income is tax exempt, except that the present value of the stamp duty and dividend tax paid is $S$. Let the total contributions by the members of the cohort and the sponsor in year $i$ be $C_{i}$, the gross rate of return on the pension scheme's investments (after deducting transactions costs and other charges) in year $i$ be $r_{i} \%$, and the annual discount rate in year $i$ be $d_{i} \%$. This cohort makes annual pension contributions for $n$ years, at which time they receive their resulting pension pot. The value of the tax free lump sum at retirement is $L$. The level of these contributions differs by a factor of $\psi$ from that required to produce a pension pot at retirement equal to the present value of the pension, creating a surplus or deficit at retirement.

The present value for this cohort of the tax paid under this EET system is:-

$$
\operatorname{PVTax}(E E T)=z \psi R / D-z L / D+S
$$

where $R=C_{n}\left(1+r_{n}\right)+C_{n-1}\left(1+r_{n}\right)\left(1+r_{n-1}\right)+C_{n-2}\left(1+r_{n}\right)\left(1+r_{n-1}\right)\left(1+r_{n-2}\right)+\ldots \ldots . .+C_{1}\left(1+r_{n}\right)\left(1+r_{n-1}\right)\left(1+r_{n-2}\right) \ldots . .\left(1+r_{1}\right)$ and $D=\left(1+d_{1}\right)\left(1+d_{2}\right)\left(1+d_{3}\right) \ldots . .\left(1+d_{n}\right)$.

The corresponding number for a pure TEE system is:-

$$
\operatorname{PVTax}(T E E)=\psi V / D
$$


where $V=C_{n} x_{n}\left(1+d_{n}\right)+C_{n-1} x_{n-1}\left(1+d_{n}\right)\left(1+d_{n-1}\right)+C_{n-2} x_{n-2}\left(1+d_{n}\right)\left(1+d_{n-1}\right)\left(1+d_{n-2}\right)+\ldots$

$$
+C_{1} x_{1}\left(1+d_{n}\right)\left(1+d_{n-1}\right)\left(1+d_{n-2}\right) \ldots .\left(1+d_{1}\right)
$$

The difference in the present values of the tax paid by the cohort under the EET and TEE systems $(Q)$ is:-

$$
Q=z \psi R / D-z L / D+S-\psi V / D=\psi(z R-V) / D-z L / D+S
$$

If the discount rate is equal to the rate of return each year on the pension fund, i.e. $r_{i}=d_{i}$ for all $i$, the marginal tax rate in employment equals that in retirement, i.e. $x_{i}=z$ for all $i$, and $L=S=0$, then:-

$V / z=C_{n}\left(1+r_{n}\right)+C_{n-1}\left(1+r_{n}\right)\left(1+r_{n-1}\right)+C_{n-2}\left(1+r_{n}\right)\left(1+r_{n-1}\right)\left(1+r_{n-2}\right)+\ldots \ldots . C_{1}\left(1+r_{n}\right)\left(1+r_{n-1}\right)\left(1+r_{n-2}\right) \ldots\left(1+r_{1}\right)$ So $\mathrm{R}=\mathrm{V} / \mathrm{z}, Q=0$ and:-

$$
\operatorname{PVTax}(\mathrm{EET})=\operatorname{PVTax}(\mathrm{TEE})
$$

